\title{
Active percussion tools from the Oldowan site of Barranco León (Orce, Andalusia, Spain): The fundamental role of pounding activities in hominin lifeways
}

Stefania Titton ${ }^{\mathrm{a}, \mathrm{b}, *}$

stefania.titton1@gmail.com

Deborah Barsky ${ }^{a, b}$

dbarsky@iphes.cat

Amèlia Bargallo ${ }^{\circ}$

a.ferrerons@ucl.ac.uk

Josep Maria Vergès ${ }^{a, b}$

jmverges@iphes.cat

Miquel Guardiola, ${ }^{\mathrm{a}, \mathrm{d}}$

esclats@gmail.com

José García Solano

jgsolano@outlook.com

Juan Manuel Jimenez Arenas

jumajia@ugr.es

Isidro Toro-Moyano

toromoyano@hotmail.com

Robert Sala-Ramos ${ }^{a, b}$

rsala@iphes.cat

alnstitut Català de Paleoecologia Humana I Evolució Social, C/Marcelli Domingo S/n, Campus Sescelades URV, Edifici W3, 43007, Tarragona, Spain

bArea de Prehistoria, Universitat Rovira I Virgili (URV), Avinguda de Catalunya 35, 43002, Tarragona, Spain

'University College London, Institute of Archaeology, Gordon Square 31-34, London, WC1HOPY, United Kingdom

dLaboratory Archaeology and Population in Africa, Department of Genetics and Evolution, Anthropology Unit, University of Geneva, 4, Boulevard D'Yvoy, 1205, Geneva, Switzerland

eUniversity of Granada, Department of Prehistory and Archaeology. Campus Universitario de Cartuja S/n, Universidad de Granada, 18071, Granada, Spain

${ }^{f}$ Archaeological Museum of Granada, Carrera Del Darro, 41-43, 18010, Granada, Spain

*Corresponding author. Institut Català de Paleoecologia Humana i Evolució Social, c/Marcelli Domingo s/n, Campus Sescelades URV, Edifici W3, 43007, Tarragona, Spain.

Abstract

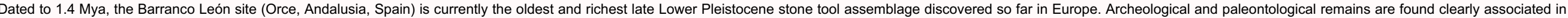

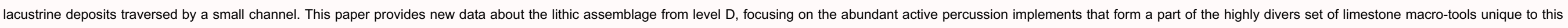

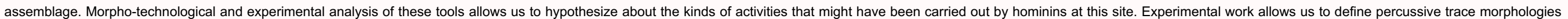




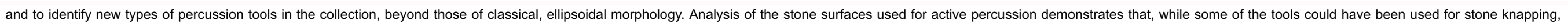

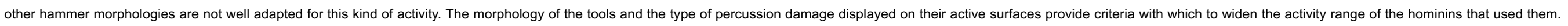
This study of the percussion instruments from Barranco León contributes essential data with which to buttress the growing interest in the macro component of Oldowan stone toolkits African and Eurasian sites and their possible uses.

Keywords: Manuport; Barranco León; Late lower pleistocene; Oldowan; Experimental archeology

\section{Introduction}

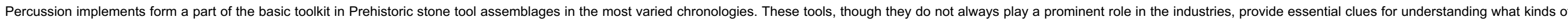

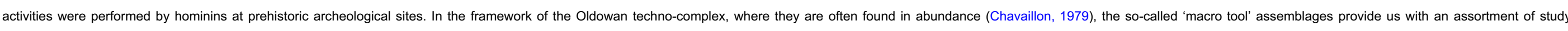

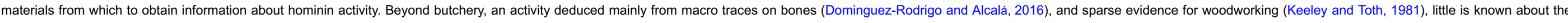

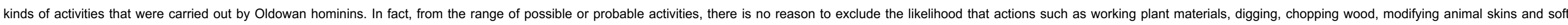
tissues, were within the range of cognitive and technical skills of these hominins.

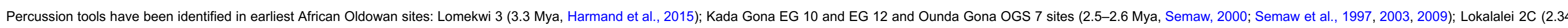

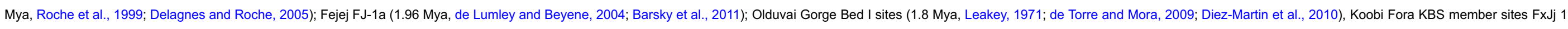

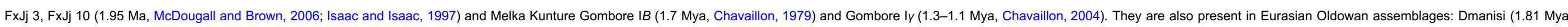

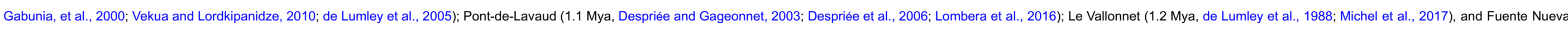

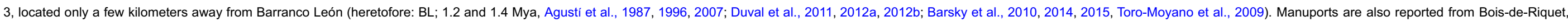

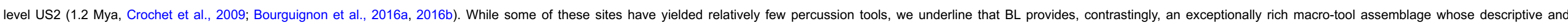
experimental analysis, provided here, will certainly serve as a database for future comparisons at all of these occurrences.

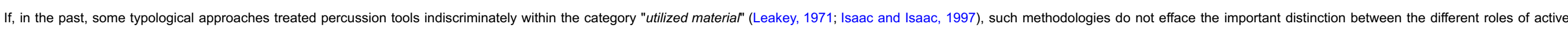

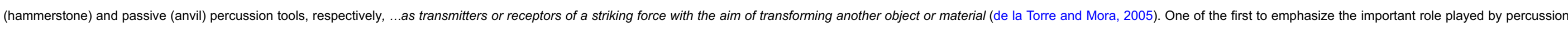

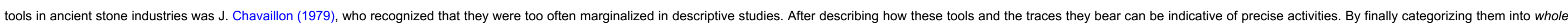
and fractured, Chavaillon (1979) pointed out that the integrity of the active percussion instruments was in relation to their use.

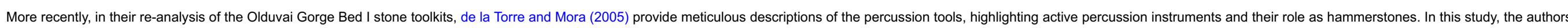

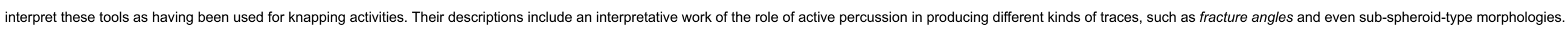

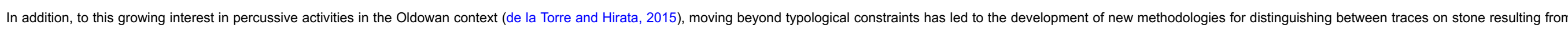

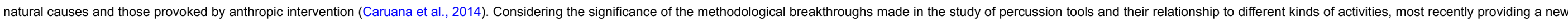

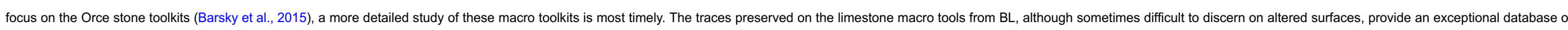

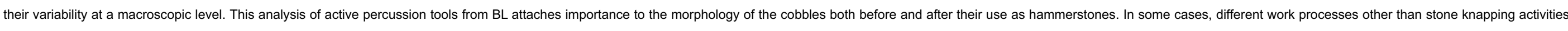
and butchery have been brought to light thanks to comparative experimental work performed on various materials (e.g. tendons, wood).

\section{The Barranco León site}

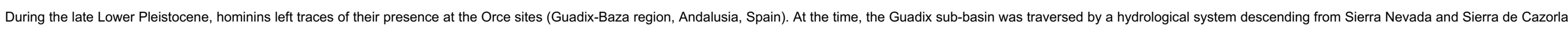

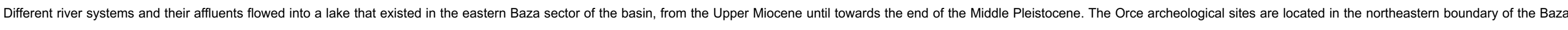

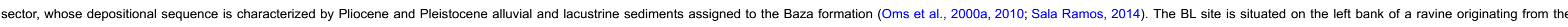

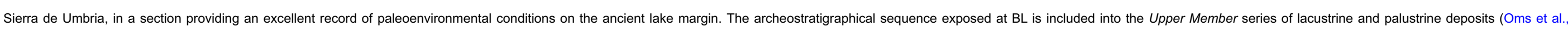




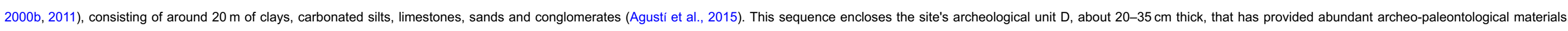

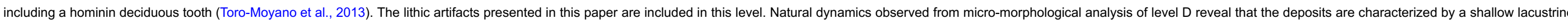

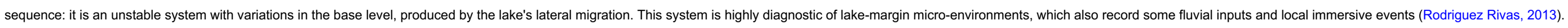

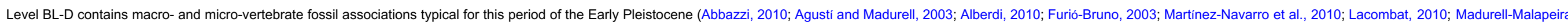

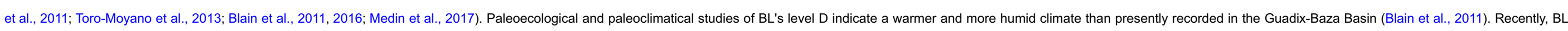

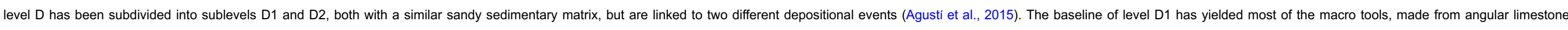
cobbles of various shapes and sizes. These cobbles are linked to high-energy currents of the paleo-channel traversing the site. Contrastingly, level D2 corresponds to an in situ formation whose sedimentary matrix contains less gravels.

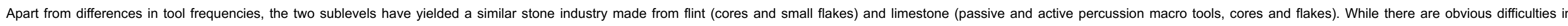

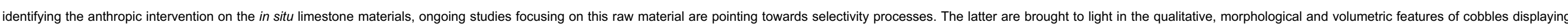

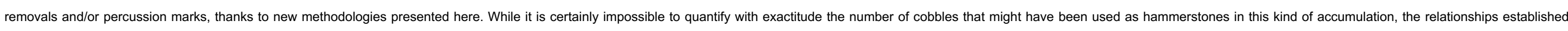

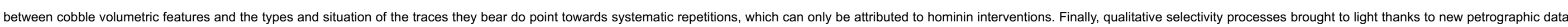
presented here concerning limestone variability at Orce lend credence to establishing hominin selective processes in some cases.

\section{Materials and methods}

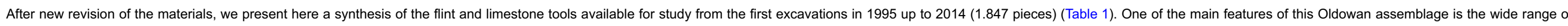

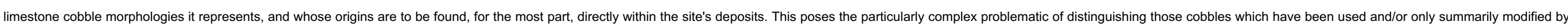

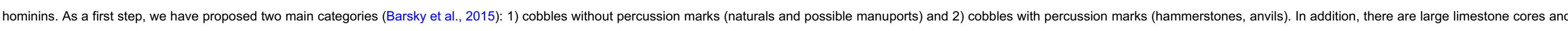
multi-functional tools, flakes and loosely configured tools. The assemblage also includes small flint flakes and fragments and abundant small-sized waste $(<2 \mathrm{~cm})$.

Table 1 Number and type of lithic items of different raw materials (1995-2014)

alt-text: Table 1

\section{Cobbles with percussion marks}

Cobbles without percussion marks

Cores and core fragments

Flakes

Debris $(>5 \mathrm{~cm})$

Debris and flake fragments $(<5 \mathrm{~cm})$

TOTALS

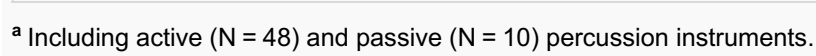

\begin{tabular}{|l|l|}
\hline 56 \\
\hline 104 \\
\hline 54 \\
\hline 56 \\
\hline 36 \\
\hline 209 \\
\hline 515 \\
\hline
\end{tabular}

Limestone Flint

\begin{tabular}{l}
2 \\
- \\
- \\
- \\
- \\
- \\
\hline 2
\end{tabular}

Calcarenite

\begin{tabular}{|l|l}
\hline- \\
\hline 40 \\
\hline 352 \\
\hline 0 \\
\hline 938 \\
\hline 1.330 \\
\hline
\end{tabular}

Total

\begin{tabular}{|l}
\hline 58 \\
104 \\
94 \\
\hline 408 \\
36 \\
\hline 1147 \\
\hline 1.847
\end{tabular}

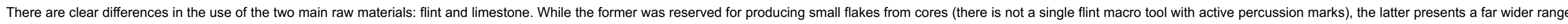

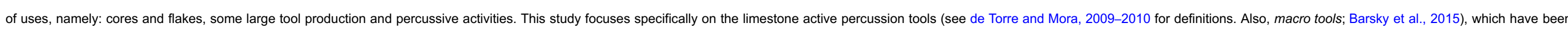

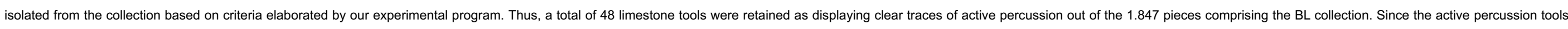

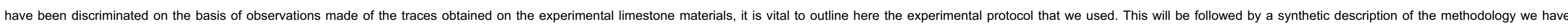

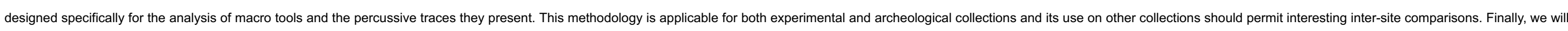
present results obtained from both the experimental and archeological active percussion tools, with special emphasis on their main morphological characteristics. 


\subsection{Experimental protocol}

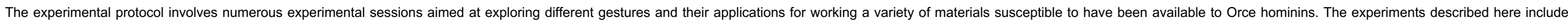

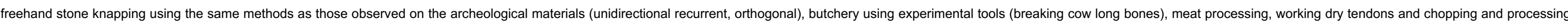
wood. These experiments have been fundamental for identifying and defining percussive trace morphologies on Orce limestone.

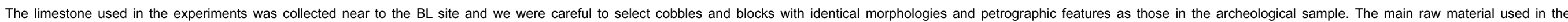
experiments is a silicified, compact limestone that was also identified as the predominant type in the archeological sample.

Experimental cobble morphologies:

- 10 ellipsoidal cobbles with curved extremities.

- 2 large blocks fractured by throwing onto a passive hammerstone (anvil) (Fr.: percussion lancée sur percuteur dormant) gave four fragments presenting potential dihedral percussive protuberances.

- 4 cobbles of irregular morphology presenting at least one trihedral-pyramidal extremity.

Each of the above morphologies was used to perform all of the tested functional experiments:

(1) stone knapping with direct hammer;

(2) bone breakage of cow forelegs (with and without anvil);

(3) wood crushing;

(4) meat and tendons processing.

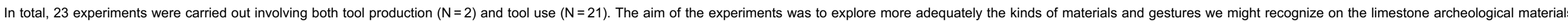

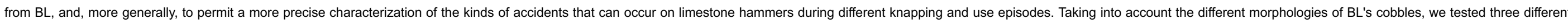
types of percussive surface areas (Fig. 1).

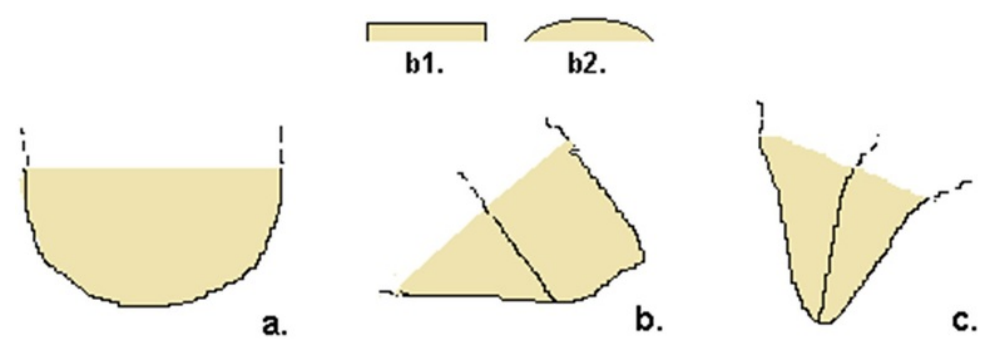

Fig. 1 Different morphology of active percussion surfaces: curved (a.); dihedral (b.); rectilinear (b1); convex (b2); trihedral-pyramidal (c.).

\section{alt-text: Fig. 1}

\subsection{Methodology for the study of archeological and experimental macro tools}

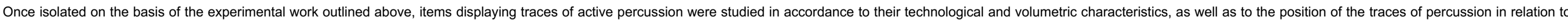
these formal aspects (Barsky et al., 2015):

Phase 1. Recognition of active percussion tools 


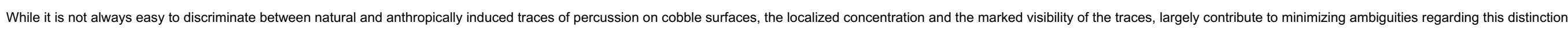

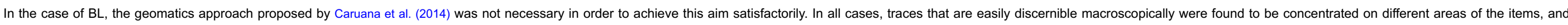
pieces were considered of anthropic origin when a systematic disposition was evidenced after the study of the highlighted attributes and comparisons with the traces produced on the experimental hammers.

\section{Phase 2. Raw materials determination}

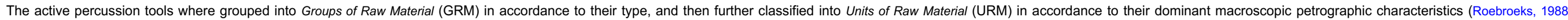
Vaquero, 2008), such as: granulometry, color and texture of the cortex, color of the matrix, presence/absence of crystallization planes, trace elements (iron oxide), fracture planes and inclusions (e.g. bioclasts).

\section{Phase 3. Positioning of the tools}

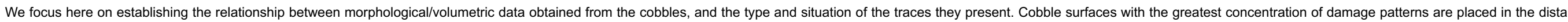

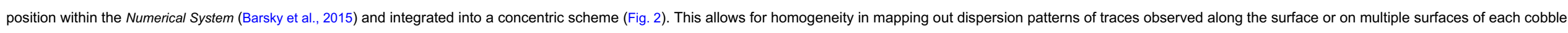

Phase 4. Morphological analysis and trace description

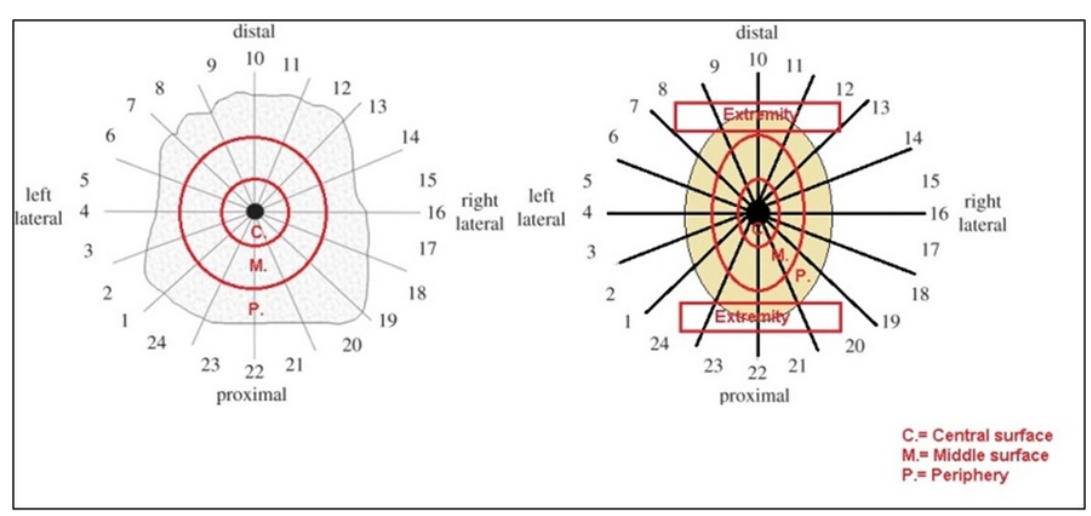

Fig. 2 Radial Numeric System for attribute location integrated by a concentric system for determination of concentration or dispersion on object surfaces (modified after Barsky et al., 2015).

alt-text: Fig. 2

The cobble (tool blank) is qualified in accordance to the following criteria:

- (a.) Type (cobble, block, slab).

- (b.) Morphology (ellipsoidal, parallelepiped, polyhedral, cubic, etc.).

- (c.) Morphology of the surface used for active percussion (flat, rounded, pointed, angular)

- (d.) Origin of percussion surface(s):

* Natural (cortex, breakage plane) or

* Anthropically generated (anthropic fracture, removals negative(s), and previous percussion damage). 


\section{Results}

\subsection{The experimental results}

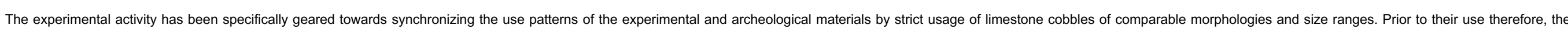

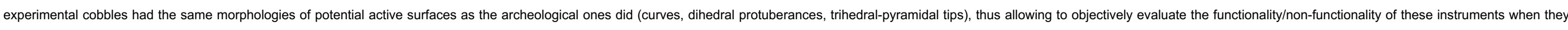
were used for different purposes (Tabl. 2). Consequently, we were able to record the type and position of the percussion damage caused by each type of activity we tested (Supplementary material 1).

\section{Ellipsoidal cobbles with rounded surfaces}

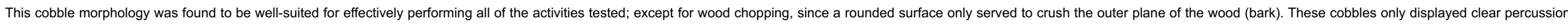

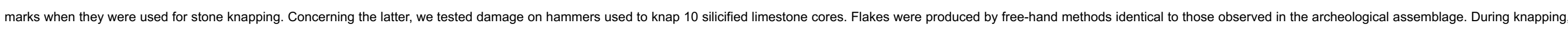

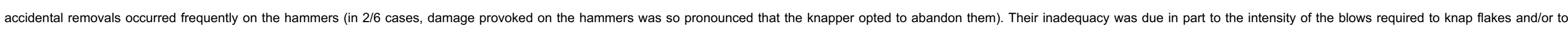
internal imperfections within the limestone itself; rather than to the number of blows delivered (Fig. 3).

\section{Cobbles presenting dihedral protrusions}

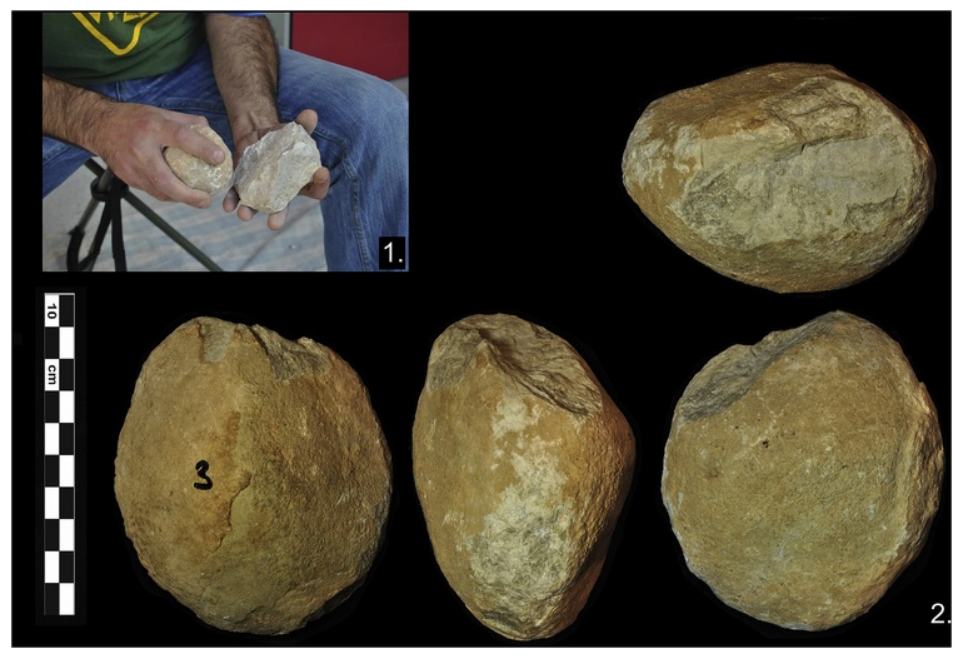

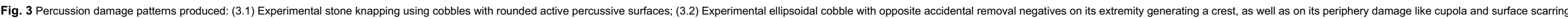
alt-text: Fig. 3

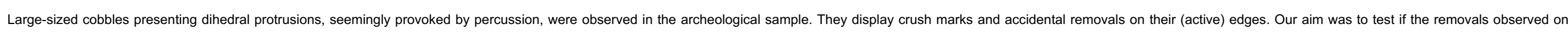

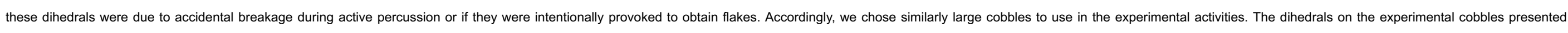
angles measuring between $67^{\circ}$ and $89^{\circ}$ (except one of $52^{\circ}$ ); in agreement with the range of the archeological pieces.

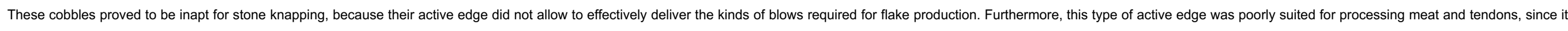

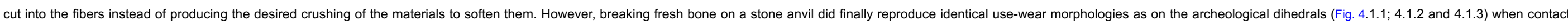

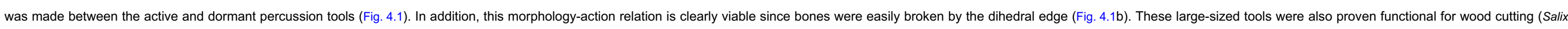


Cobbles presenting trihedral-pyramidal apexes

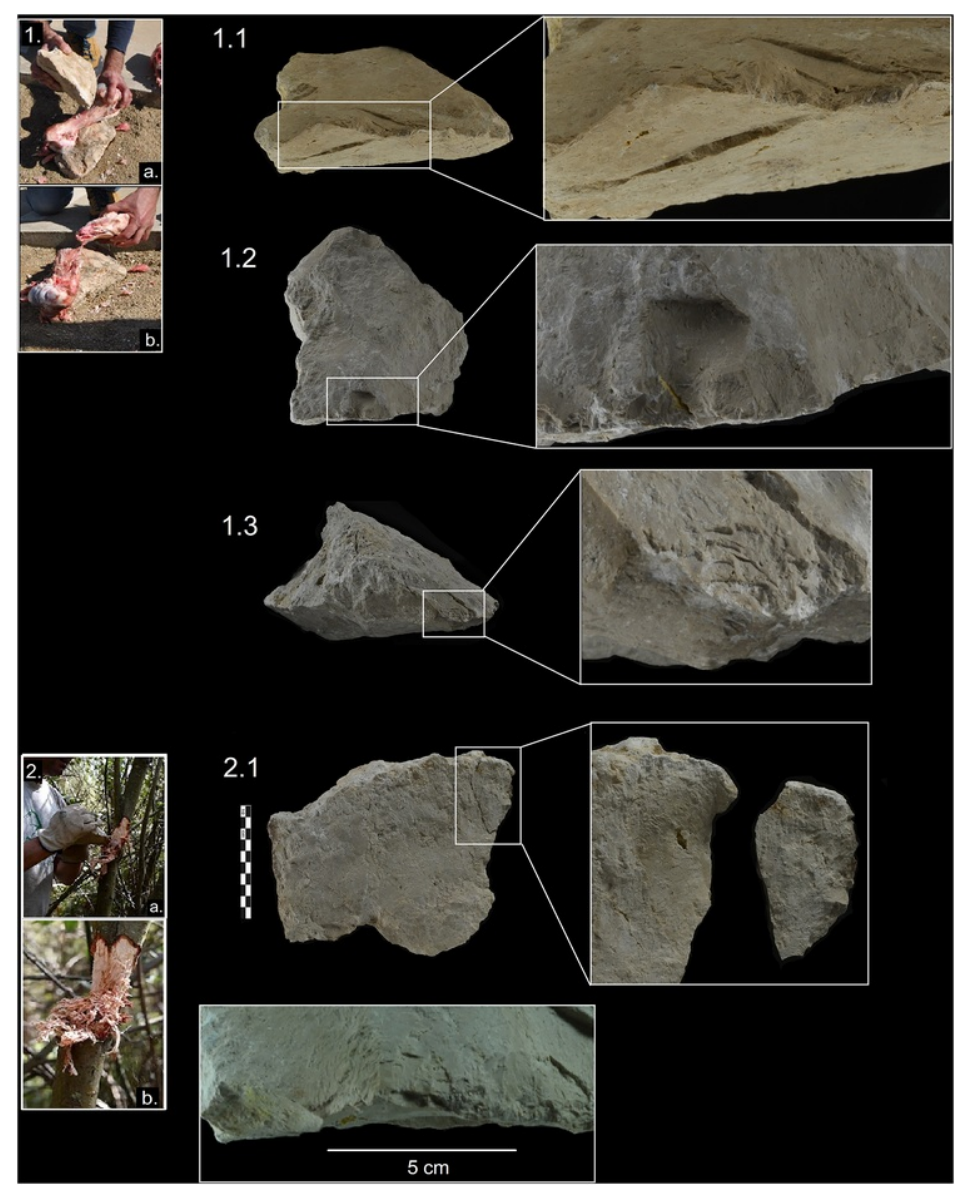

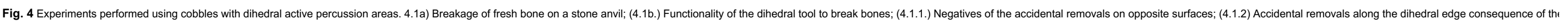

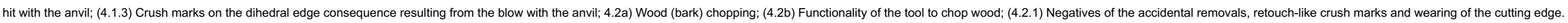
alt-text: Fig. 4 


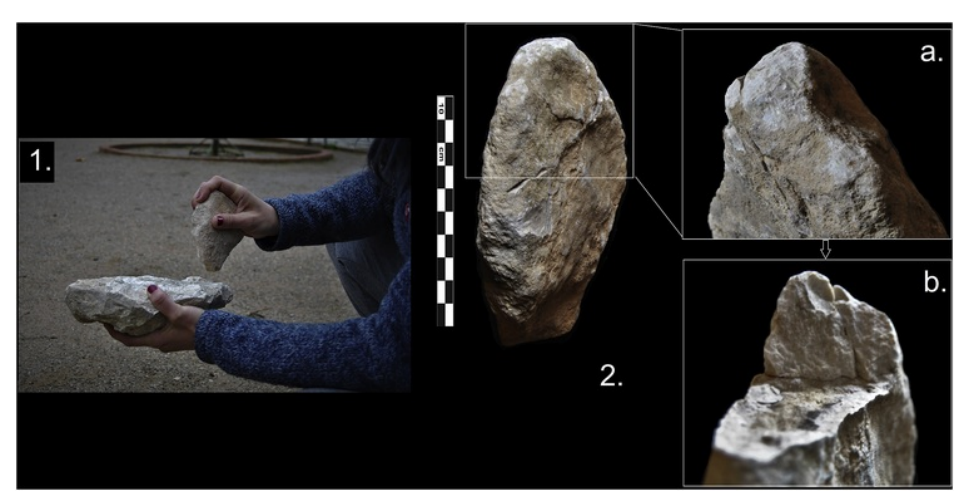

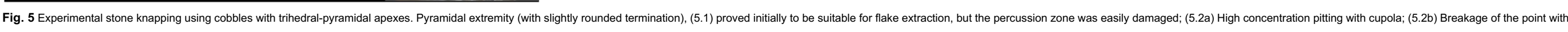
accidental removals.

alt-text: Fig. 5

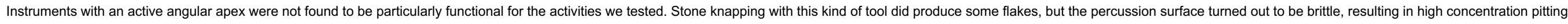

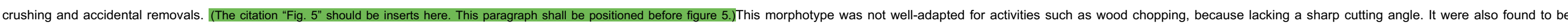
ineffective for working tendons since the pointed morphology simply destroys the fibers.

\subsection{Functionality or non-functionality of the different cobble morphologies}

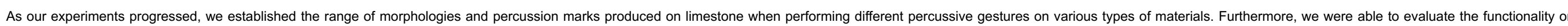

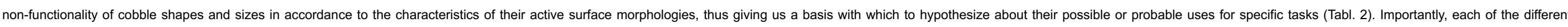

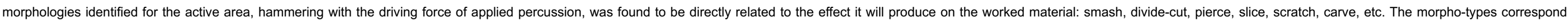
therefore, to a pre-determined surface area of potential that will or will not be useful to perform different, shape-specific tasks (Table 2).

Table 2 Functionality of the different shapes of the active percussion area and type of percussion damage generated for each of the experimental activities tested: (F) functional (NF) non-functional. alt-text: Table 2

\begin{tabular}{|c|c|c|c|c|}
\hline Experimental activity & Shape of active percussion area & Functionality & $\mathrm{N}^{\circ}$ of experiments & Type of percussion damage \\
\hline \multirow[t]{3}{*}{ Stone knapping } & Curved & $\mathbf{F}$ & 6 & cupola; accidental removal negative; facetted breakage (on crests) \\
\hline & Dihedral & NF & 1 & - \\
\hline & Trihedral-pyramidal & NF & 1 & - \\
\hline \multirow[t]{3}{*}{ Bone breaking } & Curved & $\mathbf{F}$ & 2 & not evident \\
\hline & Dihedral & $\mathbf{F}$ & 3 & accidental removals after contact with stone anvil \\
\hline & Trihedral-pyramidal & $\mathrm{NF}$ & 1 & - \\
\hline \multirow[t]{3}{*}{ Wood chopping } & Curved & NF & 1 & - \\
\hline & Dihedral & $\mathbf{F}$ & 2 & crush marks, accidental removals and polish \\
\hline & Trihedral-pyramidal & $\mathrm{NF}$ & 1 & - \\
\hline \multirow[t]{2}{*}{ Soft animal tissue processing (meat and tendons) } & Curved & $\mathbf{F}$ & 1 & not evident \\
\hline & Dihedral & NF & 1 & - \\
\hline
\end{tabular}




\subsection{The active percussion tools from Barranco León. Results from the archeological material}

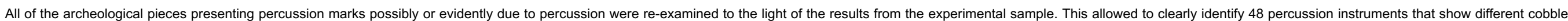
blank morphologies and display the array of percussion zone types described above (Supplementary material 2).

\subsubsection{Raw materials and volumetric features}

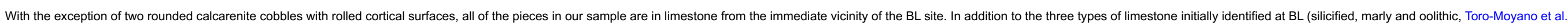

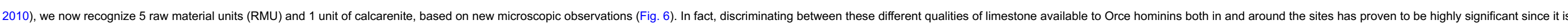
revelatory of selective processes demonstrated here by the clear dominance of silicified compact limestone (URMC1: 45,8\%) in our archeological sample (Fig. 7).

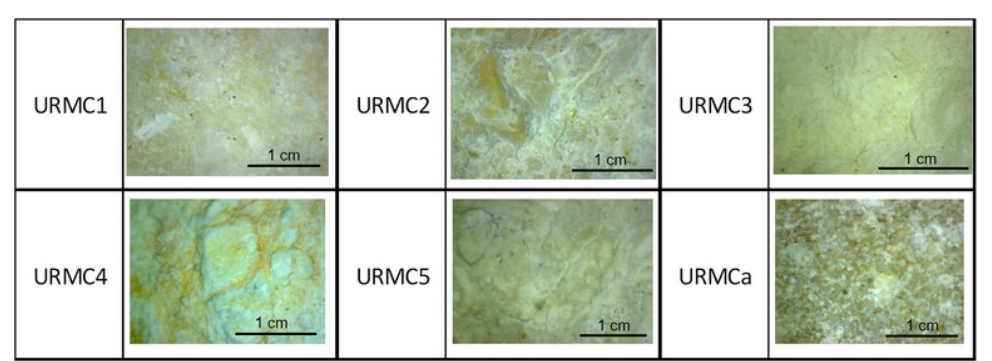

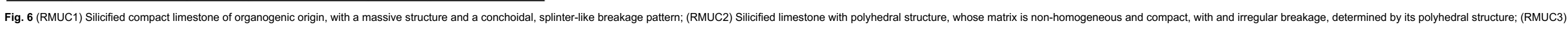

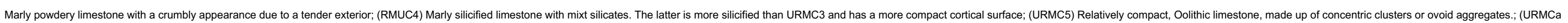
calcarenite.

alt-text: Fig. 6

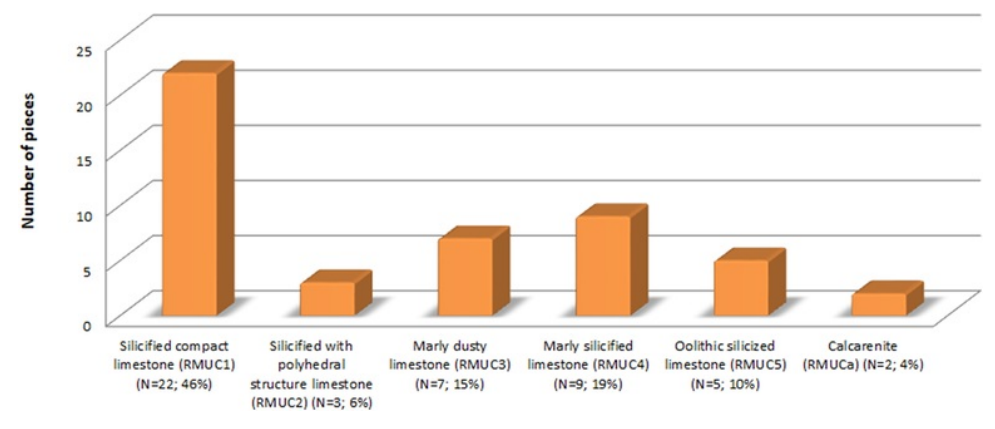

Fig. 7 Distribution of Barranco León limestone active percussion tools in accordance to each Raw Material Unit. alt-text: Fig. 7

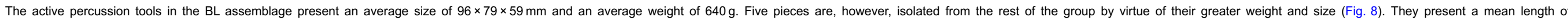
$180 \times 139 \times 101 \mathrm{~mm}$ and an average weight of $2.244 \mathrm{~g}$. Selected cobbles are whole or broken, and there are also some lightly rolled pieces (blocks) and, rarely, slabs. 


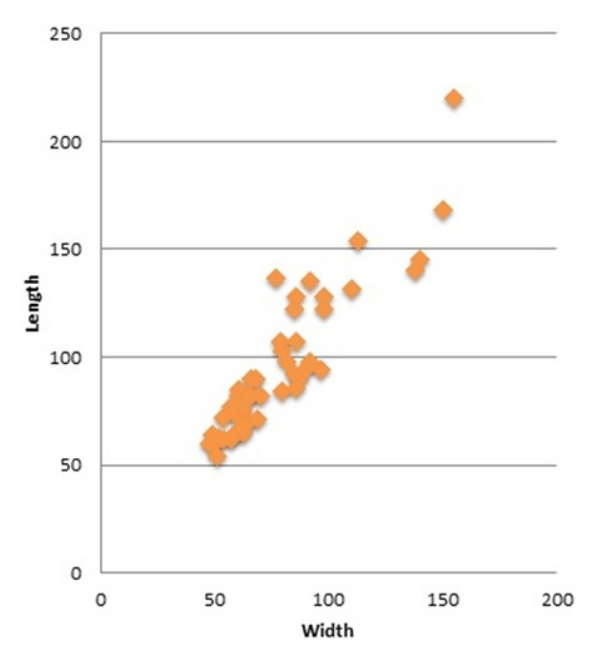

Fig. 8 Dimensions of the Barranco León active percussion tools (length and width).

alt-text: Fig. 8

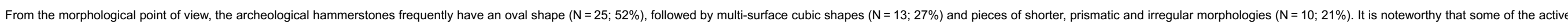

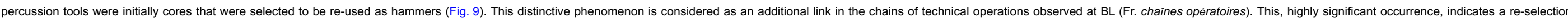

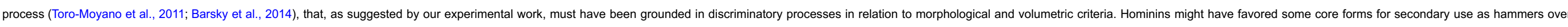
naturally available cobbles because they presented useful curved surfaces or, in some cases, exploitable orthogonal-dihedral angles from previous exploitation events that are not always naturally present on the natural cobbles (Fig. 9).

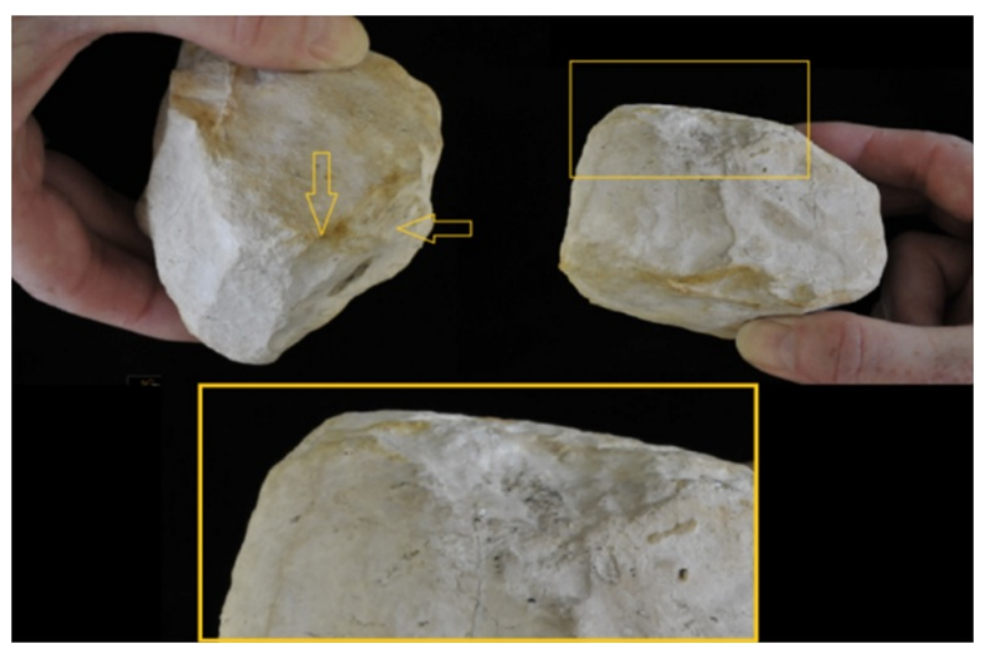

Fig. 9 Multifunctional limestone tool from Barranco León. Bipolar-on-anvil reduced core with secondary percussion marks on an angle separating a cortical surface from abrupt removal negatives. alt-text: Fig. 9

\subsubsection{Damage patterns on the Barranco León active percussion tools}

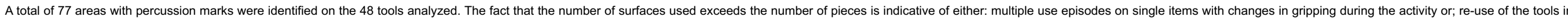

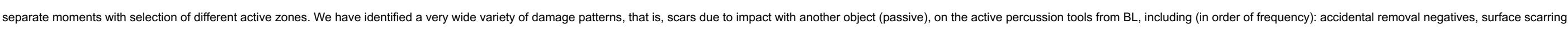




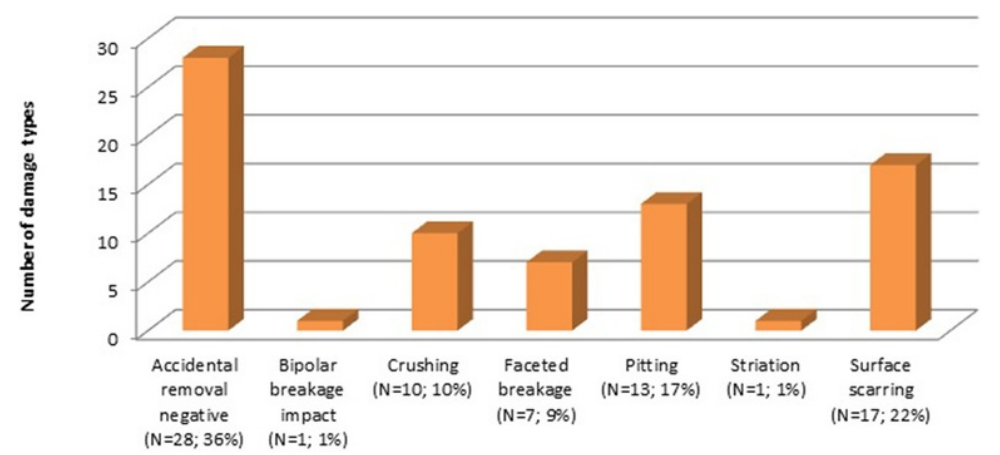

Fig. 10 Number and percentage of the different damage types identified on the active percussion tools from Barranco León.

\section{alt-text: Fig. 10}

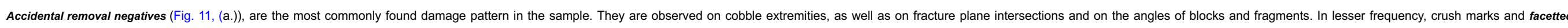

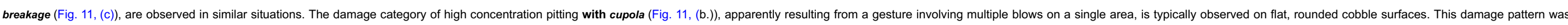

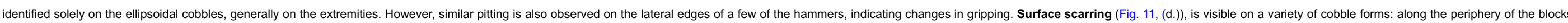

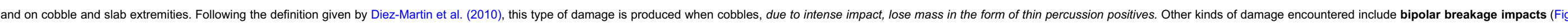
11, (e.)), located generally on cobble extremities, and striations, observed on slab peripheries.

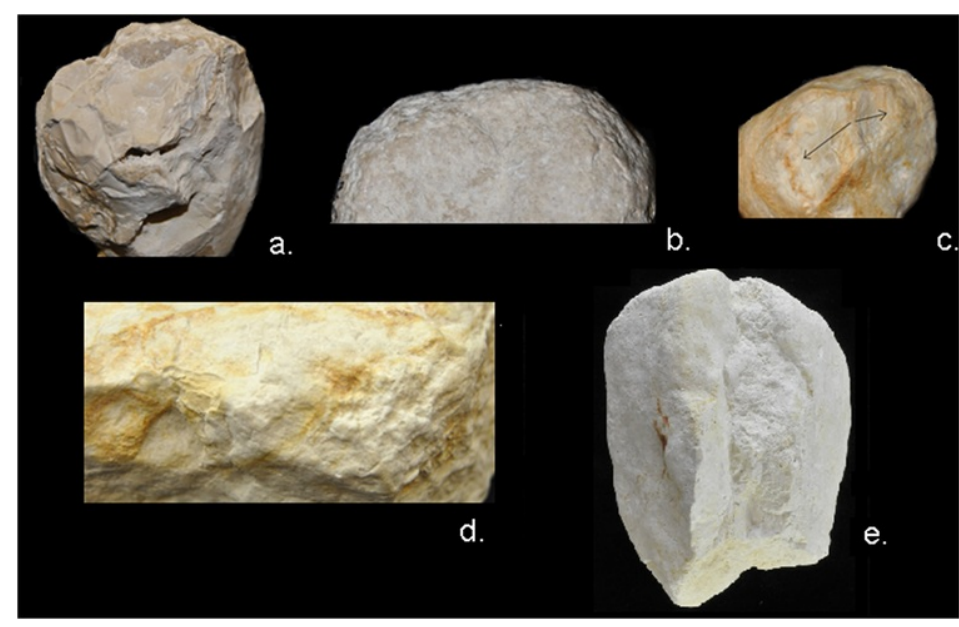

Fig. 11 Damage patterns on active percussion tools from Barranco León. (a.) Fracture angle produced by accidental removal negatives; (b.) High concentration pitting with cupola; (c.) Facetted breakage; (d) Surface scarring; (e.) Bipolar breakage impacts. alt-text: Fig. 11

\subsubsection{Correlation of surface damage patterns and cobble morphologies for the active percussion tools from Barranco León}

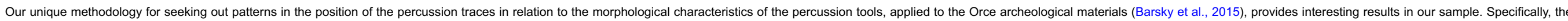

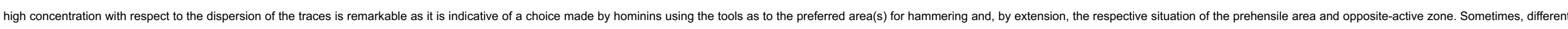
categories of percussion marks overlap or superimpose in the same area. In this case, traces can be linked, depending on the case, to intensive use of one area of a tool, or even to excessively forceful blows. 


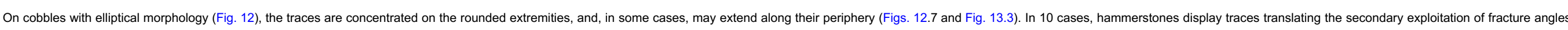

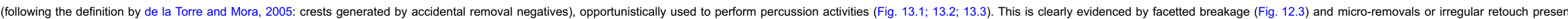
along the crest lines (Fig. 12.2).

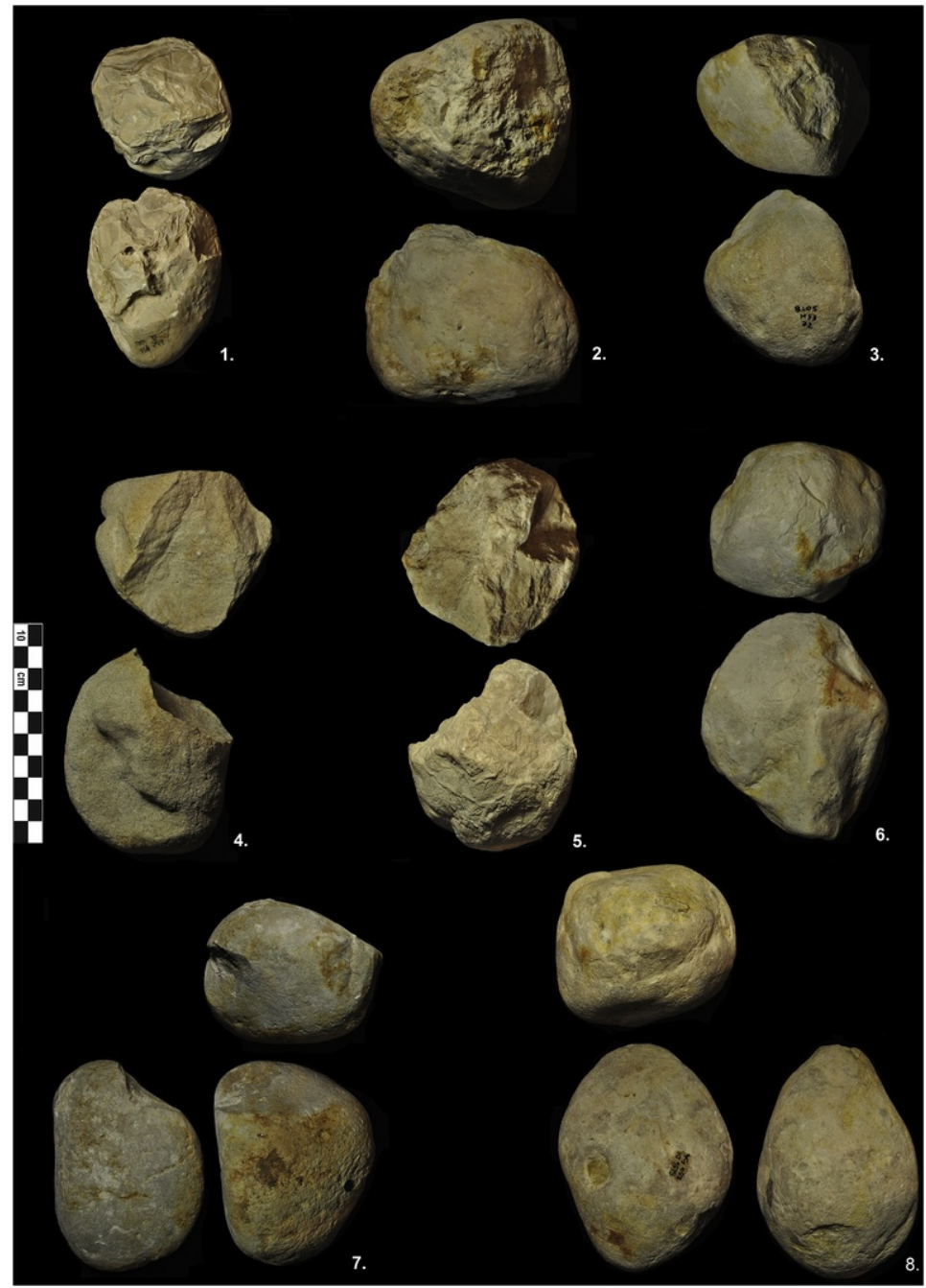

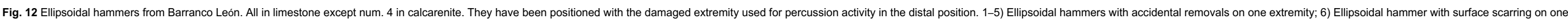

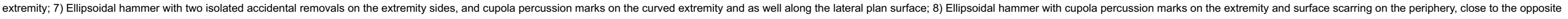
extremity.

alt-text: Fig. 12 


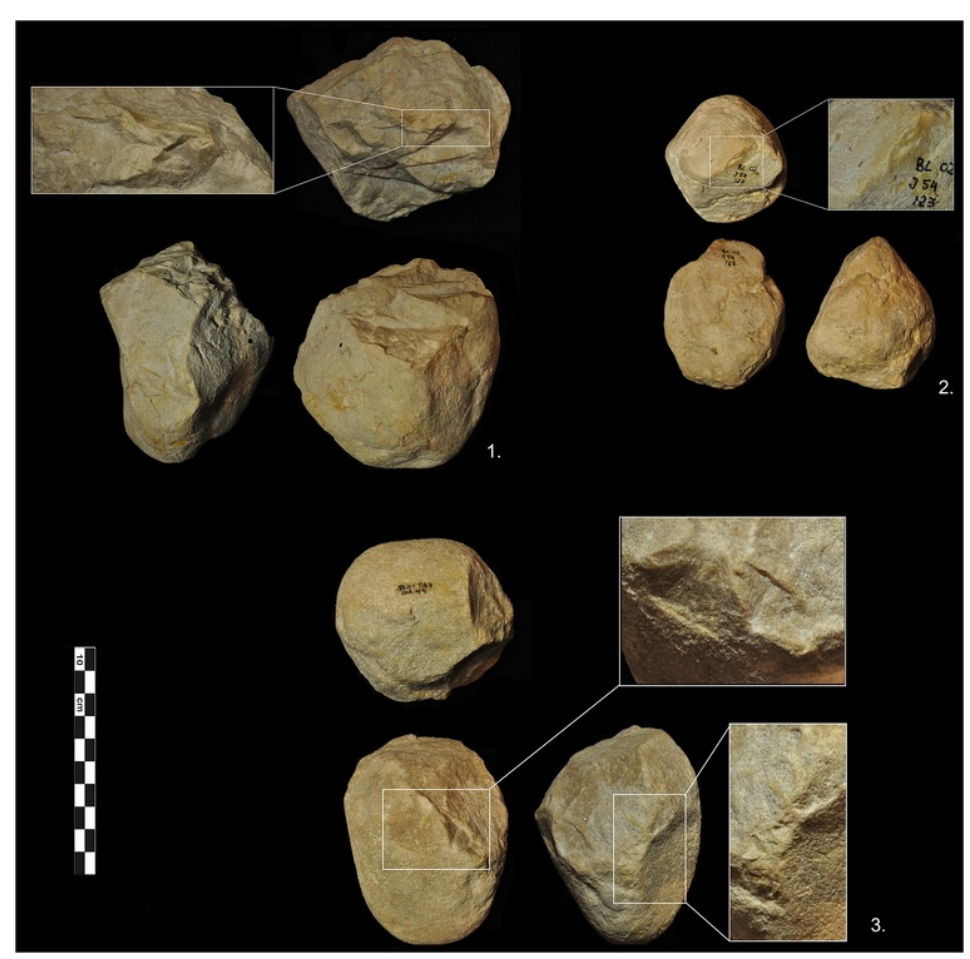

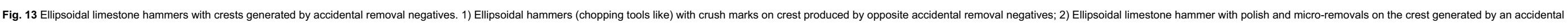
removal; 3) Ellipsoidal calcarenite hammers with splitting of accidental removals on crest and high concentration pitting and small crush masks on a crest. Localized traces on crests indicate opportunistic use. alt-text: Fig. 13

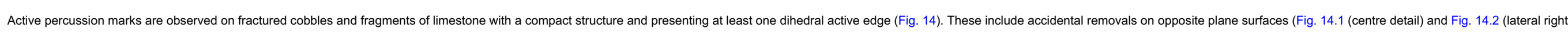

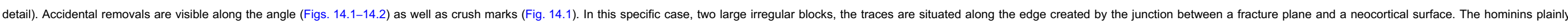
chose to use this convex dihedral edge for percussion. 


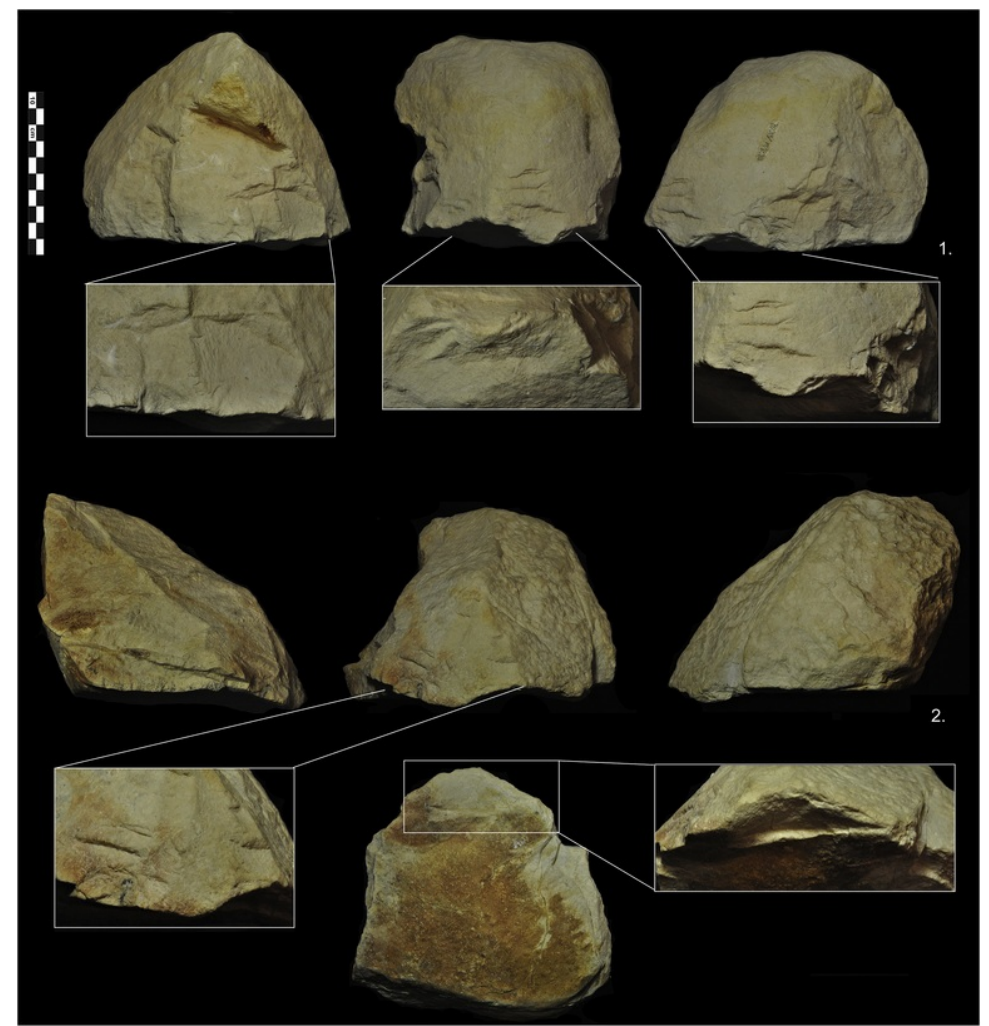

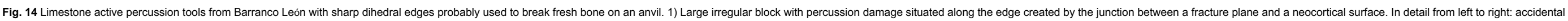

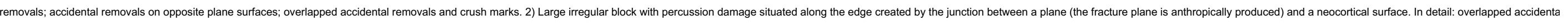
removals on opposite plane surfaces.

alt-text: Fig. 14

Some irregularly shaped pieces with protruding trihedral or even quadrilateral angles equally display crush marks, although these morphologies do not appear to have been very intensely exploited at this site (Fig. 15). 


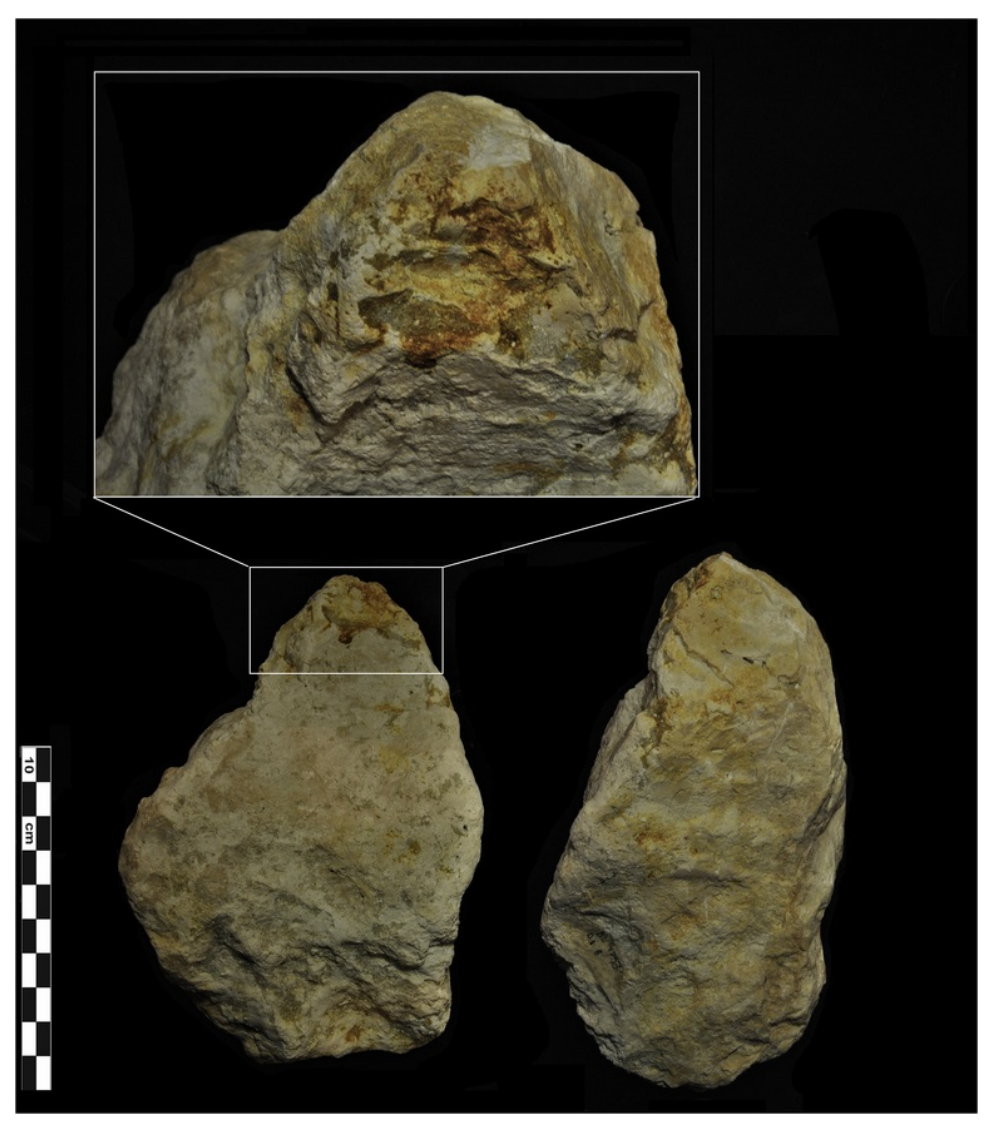

Fig. 15 Polyhedral active percussion tool with crush marks on a pyramidal extremity. alt-text: Fig. 15

\section{Discussion}

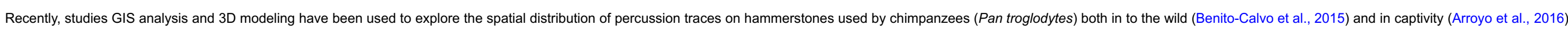

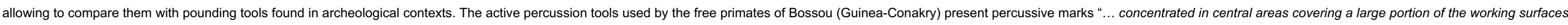

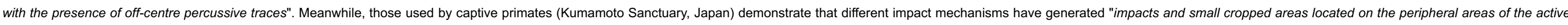
surfaces". In comparison, therefore, with our data from the hominin site of BL we make the following observations:

1) The active percussion tools from BL present different zones with clear concentrations of percussion marks, while those produced by chimpanzees tend to show a more dispersed damage pattern.

2) The chimpanzee-induced traces are concentrated on cobble peripheries, while those of BL tend to be situated on cobble extremities.

3) Active percussion tools from BL show a relatively higher degree of modification than on the primate tools: they present very visible traces that, in many cases, significantly modify the initial morphology of the percussion zone (for example: accidental removals) 4) In the case of nut-cracking, the preferred working surface used by chimpanzees tends to be flat, while curved or dihedral extremities were clearly preferred by BL hominins. 


\section{Earliest African late Lower Pleistocene sites:}

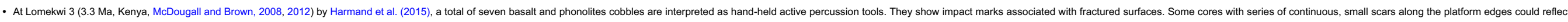
indicate that they were used for heavy-duty tasks.

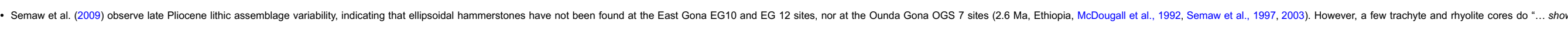
pitting/pounding marks on cortical butts, probably a result of use as hammerstones or possible use for pounding activities related to processing of animal carcasses such as for breaking bones for marrows (Semaw et al., 2009).

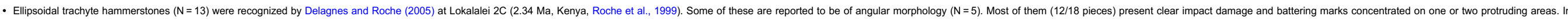
most cases, the percussion zone is situated at one or both of the extremities of the cobble, but in a few cases $(\mathrm{N}=3)$, the impact scars have a more central location.

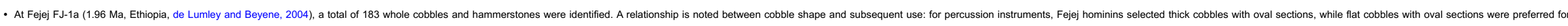

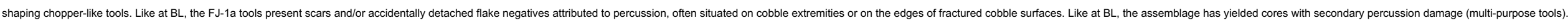

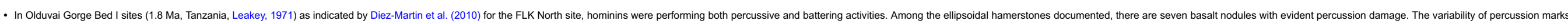

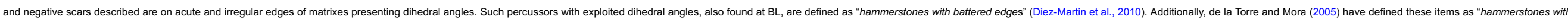

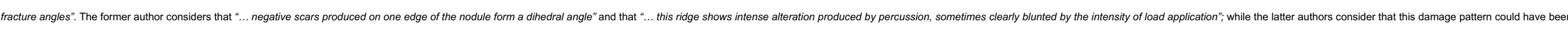

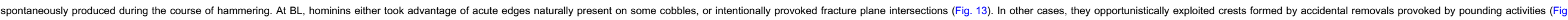
12).

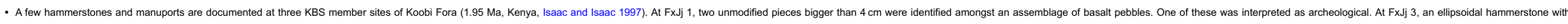
damage on its extremities was found, as well as two possible manuports coming from the surface, along the eroding outcrop of the KBS Tuff. Other non-modified rounded cobbles are documented from the FxJj 10 site, where another ellipsoidal hammer was reported.

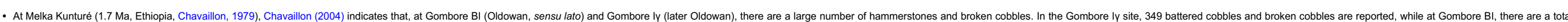
of 413 pieces described either as active hammerstones or as pitted hammerstones, as well as 1.858 battered cobbles. Beyond this quantitative indication, that underlines the importance of such tools in these lithic assemblages, no detailed morphological description is avaliable yet

\section{- Earliest Eurasian Oldowan sites:}

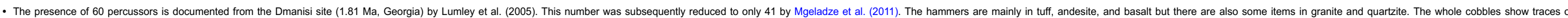
percussion on their extremities, as well as on lateral peripheries. The fractured cobbles and/or those with isolated accidental, removals are also considered to have been used for active percussion. In some cases these hammers show traces of their subsequent use as anvils or nuclei.

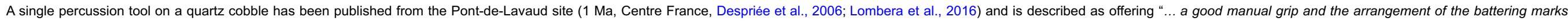

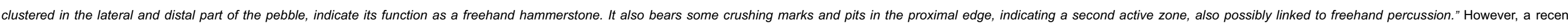

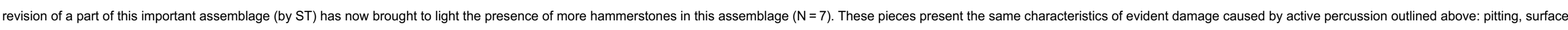
scarring, accidental removals and double faceted breakage. They present a range of dimensions and have ellipsoidal and elongated ovaloid morphologies.

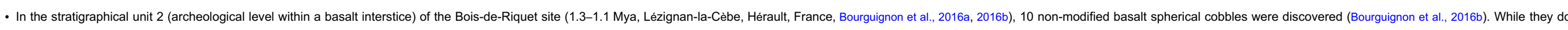

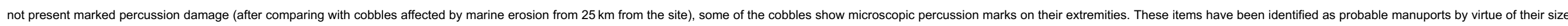

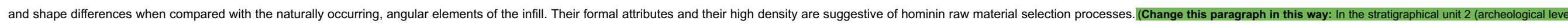

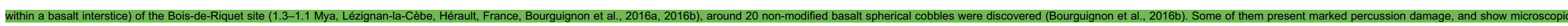




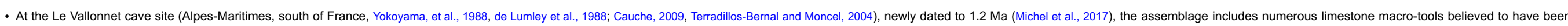

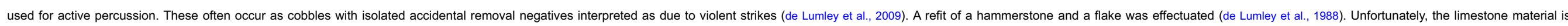
strongly altered, impeding clear visibility of other types of percussion marks that could potentially be documented. Some limestone cores also show traces indicating that they were used as hammers.

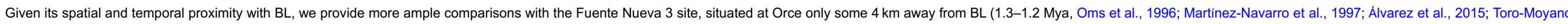

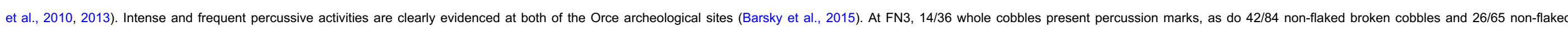

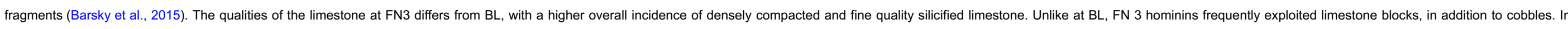

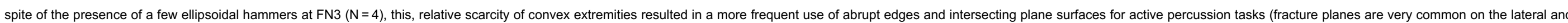

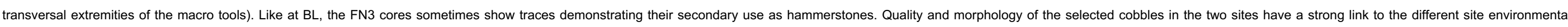

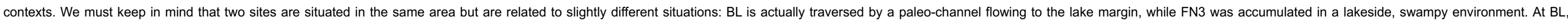
therefore, rounded cobbles were brought directly into the site by the currents of the paleo-channel, while at FN3 the exact source of the rounded cobbles has not yet been localized.

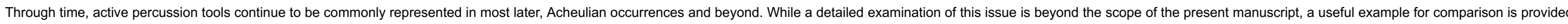

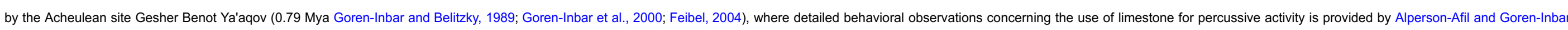

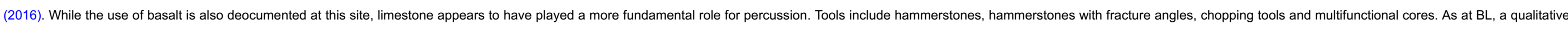

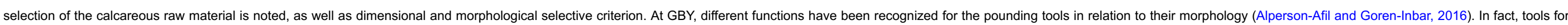

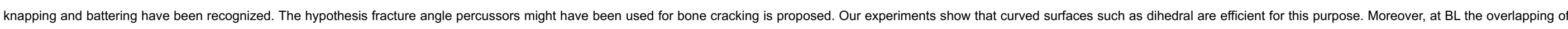

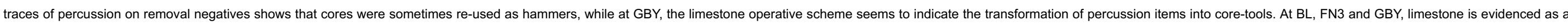

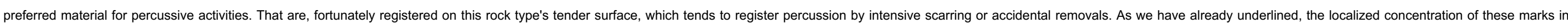

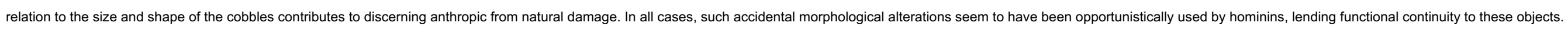

\section{Conclusions}

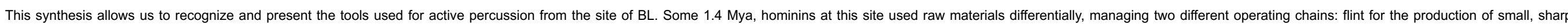

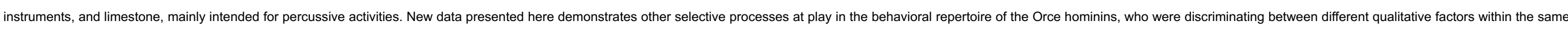

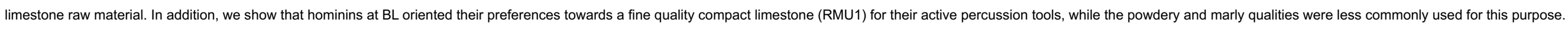

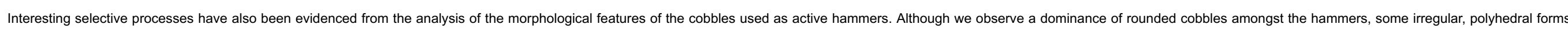

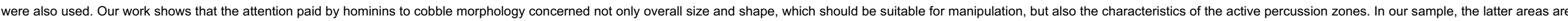
preferentially curved, or sometimes dihedral or trihedral.

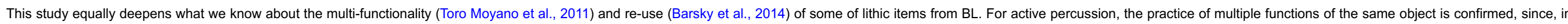

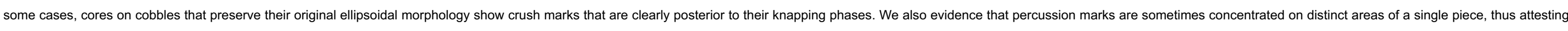

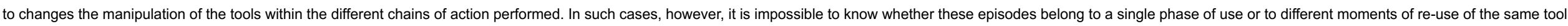

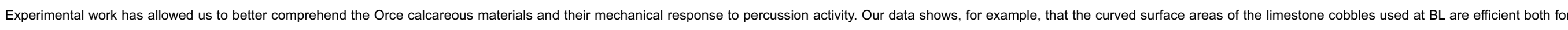

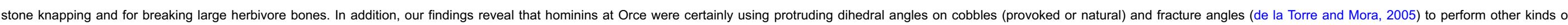

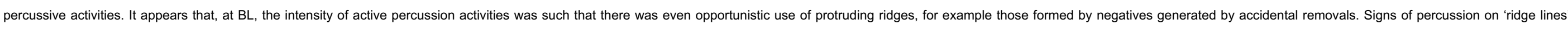
reveals that even 'damaged' tools were opportunistically used; rather than abandoned due to functional loss.

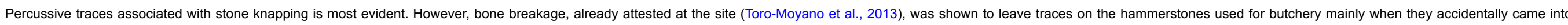




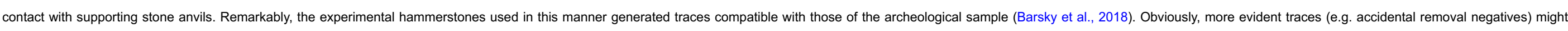

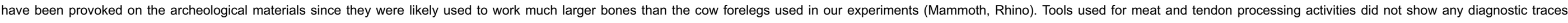

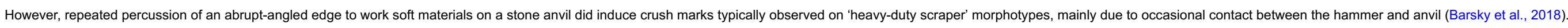

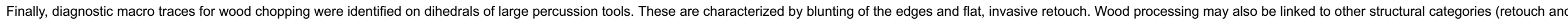

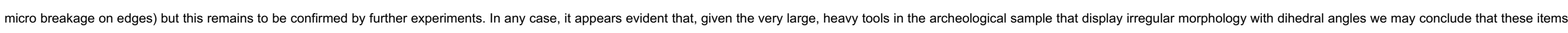
were not useful for core exploitation due to the irregularity of their active surfaces and their difficult manipulation.

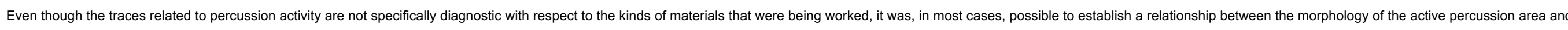

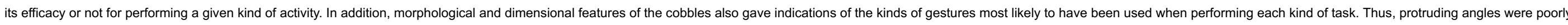

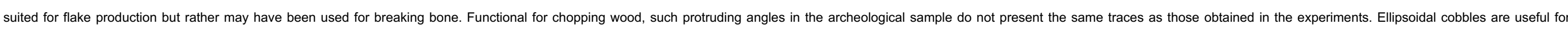

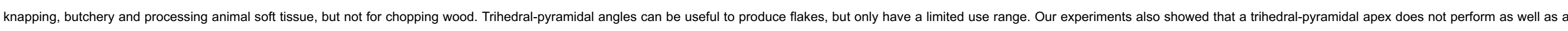

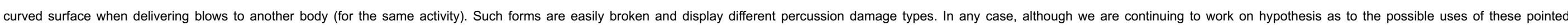
morphologies, the percussion damage recognized on the archeological materials clearly indicates their use for some kind of pounding activity.

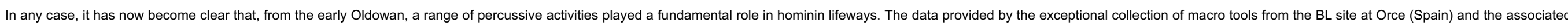
experimental work presented here, provides a glimpse towards the functional aspects that these tools could, potentially, reveal to us.

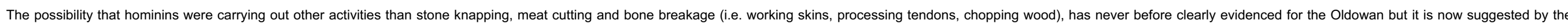

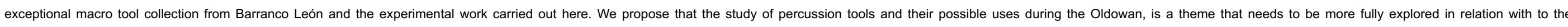

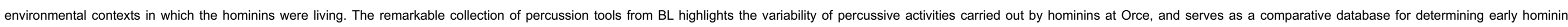
behaviors and lifestyles at other African and Eurasian Oldowan sites.

\section{Acknowledgements}

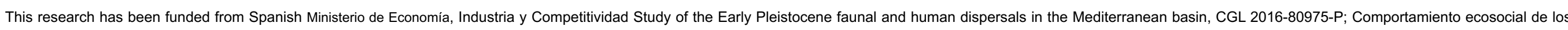

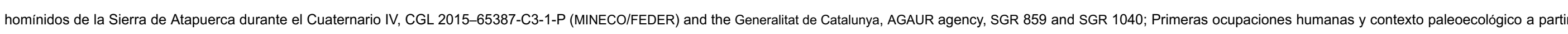

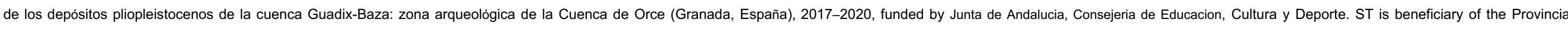

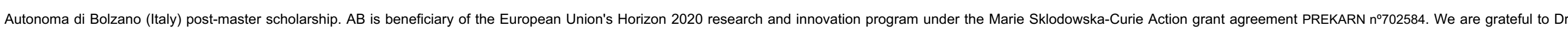

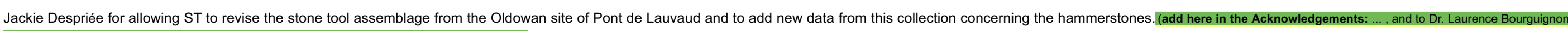
and Dr. Louis De Weyer for the updating on the study of the manuports of the Bois-de-Riquet site.)

\section{Appendix A. Supplementary data}

Supplementary data related to this article can be found at https://doi.org/10.1016/j.jas.2018.06.004.

\section{References}

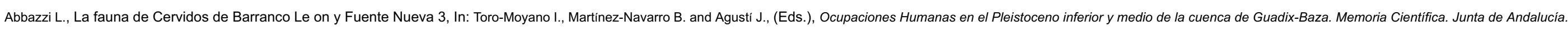
Consejería de Cultura. E.P.G. Arqueología Monografico, Sevilla, 2010, 273-290.

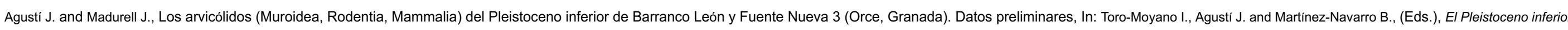
de Barranco León y Fuente Nueva 3, Orce (Granada). Memoria Cientifica Campañas 1999-2002. Junta de Andalucía. Consejería de Cultura. E.P.G. Arqueología Monográfico, Sevilla, 2003 , 137-145.

Agustí J., Arbiol S. and Martin-Suarez E., Roedores y lagomorfos (Mammalia) del Pleistoceno inferior de Venta Micena (Depresión de Guadix-Baza, Granada), Paleontologia i Evolució, Memoria Especial 1, $1987,95-107$.

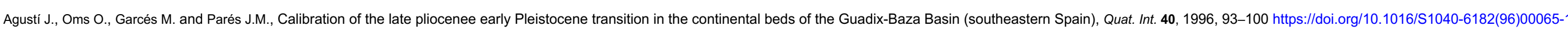




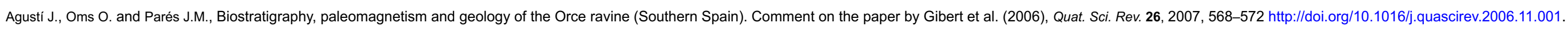

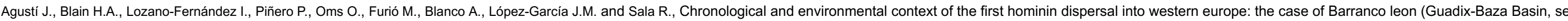
Spain), J. Hum. Evol. 87, 2015, 87-94 http://doi.org/10.1016/j.jhevol.2015.02.014.

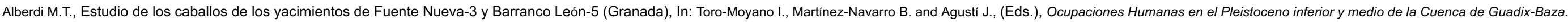
Junta de Andalucía. Consejería de Cultura. Arqueología Monográfico, Sevilla, 2010, 291-306.

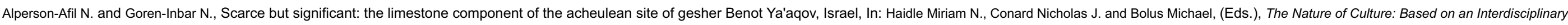
Symposium 'The Nature of Culture', Tübingen, Germany, Vertebrate Paleobiology and Paleoanthropology, 2016 https//doi.org/10.1007/978-94-017-7426-0_5.

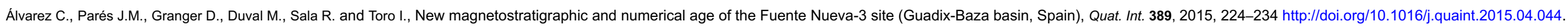

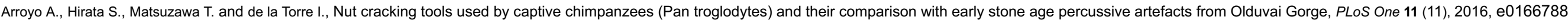
https://doi.org/10.1371/journal.pone.0166788.

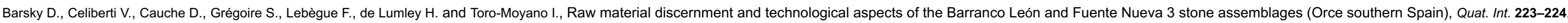
2010, 201-219 http://doi.org/10.1016/j.quaint.2009.12.004.

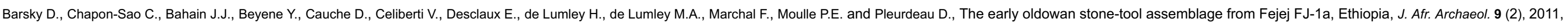
207-224 http://doi.org/10.3213/2191-5784-10196.

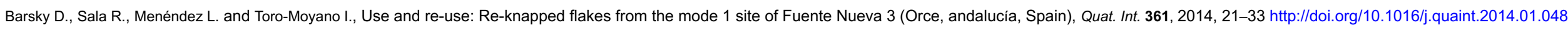

Barsky D., Vergès J.M., Sala R., Menéndez L. and Toro-Moyano I., Limestone percussion tools from the late early Pleistocene sites of BarrancoLeón and Fuente Nueva 3 (Orce Spain), Phil Trans R Soc B 370 (20140352), 2015 http://doi.org/10.1098/rstb.2014.0352.

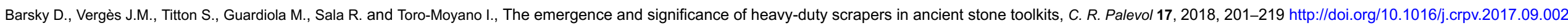

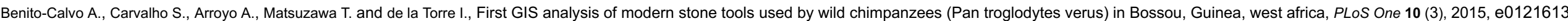
https://doi.org/10.1371/journal.pone.0121613.

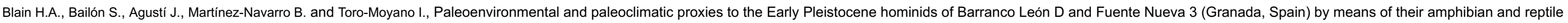
assemblages, Quat. Int. 243 (1), 2011, 44-53 http://doi.org/10.1016/j.quaint.2010.12.031.

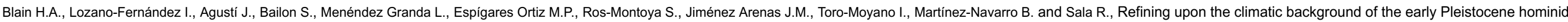
settlement in western europe: Barranco León and Fuente Nueva-3 (Guadix-Baza Basin, se Spain), Quat. Sci. Rev. 144, 2016, 132-144 http://doi.org/10.1016/j.quascirev.2016.05.020.

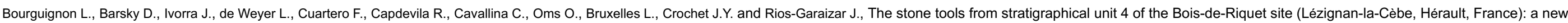
milestone in the diversity of the European Acheulian, Quat. Int. 411, 2016a, 160-181 http://doi.org/10.1016/j.quaint.2016.01.065.

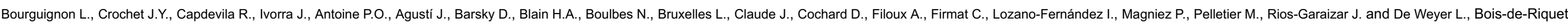
(Lézignan-la-Cèbe, Hérault): a late Early Pleistocene archaeological occurrence in southern France, Quat. Bar Int. 393, 2016b, 24-40 http://doi.org/10.1016/j.quaint.2015.06.037.

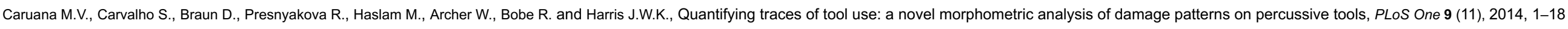
http://doi.org/10.1371/journal.pone.0113856.

Cauche D., Les stratégies de débitage dans les industries lithiques archaïques des premiers habitants de l'Europe, Anthropologie 113 (1), 2009, 178-190 http://doi.org/10.1016/j.anthro.2009.01.012. 
Chavaillon J., Essai pour une typologie du matériel de percussion, Bull. Soc. Prehist. Fr. 76, 1979, 230-233.

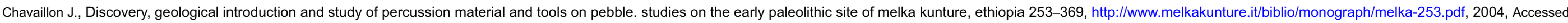
20 March 2018

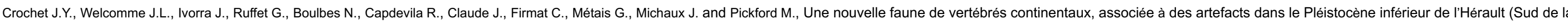
France), vers 1,57 Ma, C.R. Palevol 8, 2009, 725-736 http://doi.org/10.1016/j.crpv.2009.06.004.

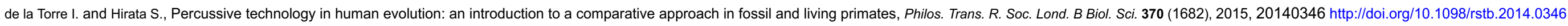
de la Torre I. and Mora R., Technological Strategies in the Lower Pleistocene at Olduvai Beds I \& II, 2005, University of Liege Press; Brussels, Eraul 112.

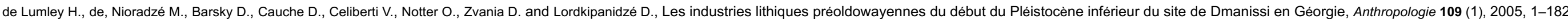
http://doi.org/10.1016/j.anthro.2005.02.011.

de Lumley H. and Beyene Y., Les sites préhistoriques de la région de Fejej, Sud-Omo, Ethiopie, dans leur contexte stratigraphique et paléontologique. Editions Recherche sur les civilisations, Paris, 2004.

de Lumley H., Fournier A., Krzepkowska J. and Echassoux A., L'industrie du Pléistocène inférieur de la grotte du Vallonnet, Roquebrune-Cap-Martin, Alpes-Maritimes, L'Anthropologie 92 (2), 1988, 501-614.

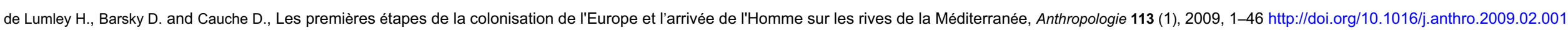

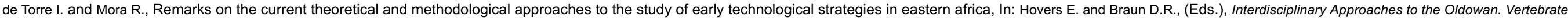

Paleobiology and Paleoanthropology, 2009, Springer; Dordrecht, 15-24 http://doi.org/10.1007/978-1-4020-9060-8_2.

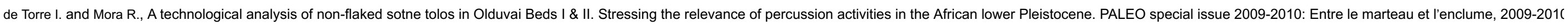
13-34 http://paleo.revues.org/1877.

Delagnes A. and Roche H., Late Pliocene hominid knapping skills: the case of Lokalalei 2C, west turkana, Kenya, J. Hum. Evol. 48 (5), 2005, 435-472 http://doi.org//10.1016/j.jhevol.2004.12.005.

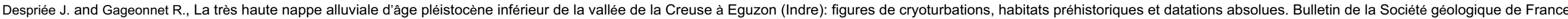

174(4), 383-400, http://hdl.handle.net/2042/270, 2003, Accessed 20 March 2018.

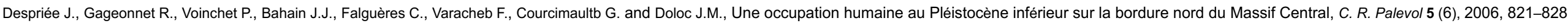
http://doi.org/10.1016/j.crpv.2006.03.001.

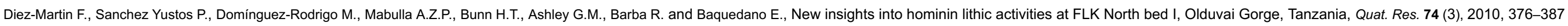

http://doi.org/10.1016/j.yqres.2010.07.019.

Dominguez-Rodrigo M. and Alcalá L., 3.3-Million-Year-Old stone tools and butchery Traces? More evidence needed, PaleoAnthropology 2016, 46-53 http://doi.org/10.4207/PA.2016.ART99.

Duval M., Aubert M., Hellstrom J. and Grün R., High resolution LA-ICP-MS mapping of U and Th isotopes in an early Pleistocene equid tooth from Fuente Nueva-3 (Orce, Andalusia, Spain), Quat. Geochronol. 6, 2011, 458-467

http://doi.org/10.1016/j.quageo.2011.04.002.

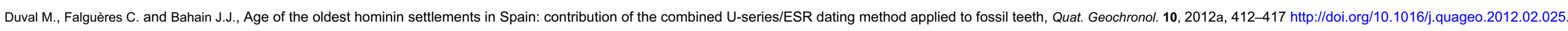

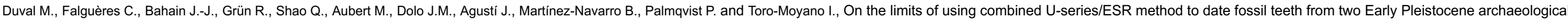
sites of the Orce area (Guadix-Baza basin, Spain), Quat. Res. 77 (3), 2012b, 482-491 http://doi.org/10.1016/j.yqres.2012.01.003.

Feibel C.S., Quaternary lake margins of the levant rift valley, In: Goren-Inbar N. and Speth J.D., (Eds.), Human Paleoecology in the Levantine Corridor, 2004, Oxbow Books; Oxford, $21-36$. 


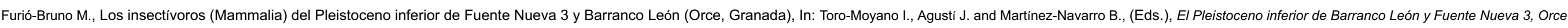
(Granada). Memoria Cientifica campañas 1999-2002. Junta de Andalucía. Consejería de Cultura. E.P.G. Arqueología Monografico 17, Sevilla, 2003, $147-157$.

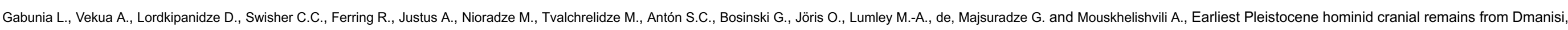
Republic of Georgia: taxonomy, geological setting, and age, Science 288 (5468), 2000, 1019-1025 http://doi.org/10.1126/science.288.5468.1019.

Goren-Inbar N. and Belitzky S., Structural position of the Pleistocene gesher Benot Ya'aqov site in the dead sea rift zone, Quat. Res. 31, 1989, 371-376 https://doi.org/10.1016/0033-5894(89)90043-4.

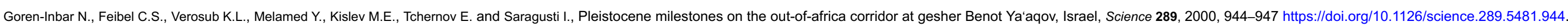

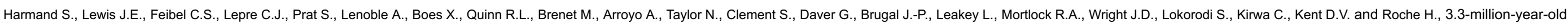
stone tools from Lomekwi 3, west turkana, Kenya, Nature $\mathbf{5 2 1}$ (7552), 2015, 310-315 http://doi:10.1038/nature14464.

Isaac G.L. and Isaac B., (Eds.), Koobi Fora Research Project, volume 5: Plio-Pleistocene archaeology, 1997, Clarendon Press; Oxford.

Keeley L.H. and Toth N., Microwear polishes on early stone tools from Koobi Fora, Kenya, Nature 293, 1981, 464-466 http://doi.org/10.1038/293464a0.

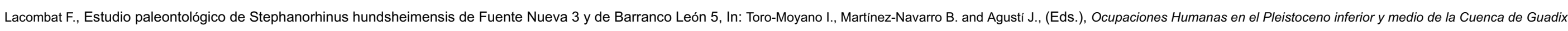
Baza. Junta de Andalucía. Consejería de Cultura. E.P.G. Arqueología Monográfico, Sevilla, 2010, 237-246.

Leakey M.D., Olduvai Gorge vol. 3, 1971, Cambridge University Press; Cambridge, 1960-1963, Excavations in Beds I and II.

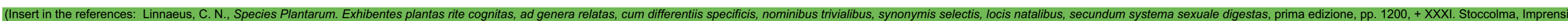

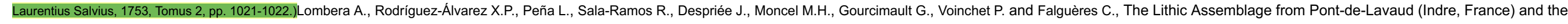

Role of the Bipolar-on-anvil Technique in the Lower and Early Middle Pleistocene Technology, J. Anthropol. Archaeol. 41, 2016, 159-184 http://doi.org/10.1016/j.jaa.2015.12.002.

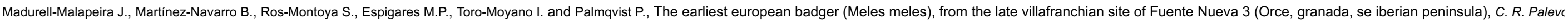
10 (8), 2011, 609-615 http://doi.org/10.1016/j.crpv.2011.06.001.

Martínez-Navarro B., Turq A., Ballester J. and Oms O., Fuente Nueva-3 (Orce, granada, Spain) and the first human occupation of europe, J. Hum. Evol. 33, 1997, 611-620 https://doi.org/10.1006/jhev.1997.0158.

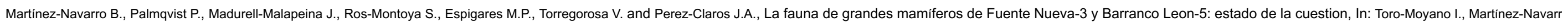

B. and Agusti J., (Eds.), Ocupaciones humanas en el Pleistoceno inferior y medio de la cuenca de Guadix-Baza. Junta de Andalucía. Consejería de Cultura. E.P.G. Arqueología Monográfico, Sevilla, 2010, 197-326.

McDougall I. and Brown F.H., Precise 40Ar/39Ar geochronology for the upper Koobi Fora formation, turkana basin, northern Kenya, J. Geol. Soc. 163, 2006, 205-220 https://doi.org/10.1144/0016-764904-166.

McDougall I. and Brown F.H., Geochronology of the pre-KBS tuff sequence, turkana basin, J. Geol. Soc. 165 (2), 2008, 549-562 http://doi.org/10.1144/0016-76492006-170.

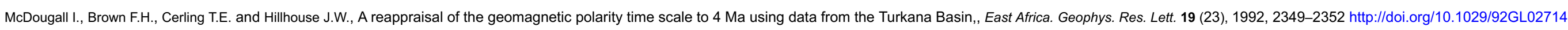

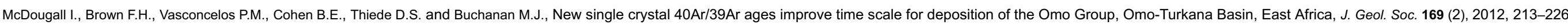

http://doi.org/10.1144/0016-76492010-188.

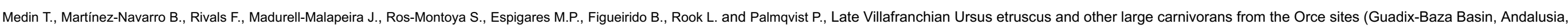

Southern Spain): taxonomy, biochronology, paleobiology and ecogeographical context, Quat. Int. 431 (B), 2017, 20-41 http://doi.org/10.1016/j.quaint.2015.10.053.

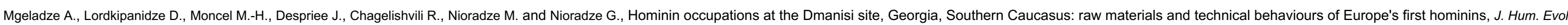

60 (5), 2011, 571-596 http://doi.org/10.1016/j.jhevol.2010.10.008.

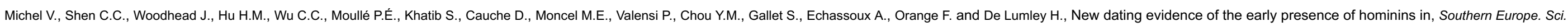


Rep. 7 (1), 2017, 1-8 http://doi.org/10.1038/s41598-017-10178-4.

Oms O., Dinares Turell J. and y Parés J.M., Resultados paleomagnéticos iniciales de la sección Plio-Pleistocena de Fuente Nueva (Cuenca de Guadix-Baza, Cordilleras Béticas), Rev. Soc. Geol. Espana 9 (1-2), 1996, 89-95, 0deec52c450b9ac18c000000.pdf Accessed 3 April 2018.

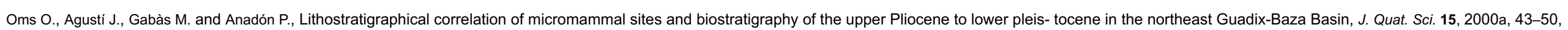
http://doi.org/10.1002/(SICI)1099-1417(200001)15:1<43::AID-JQS475>3.0.CO;2-9.

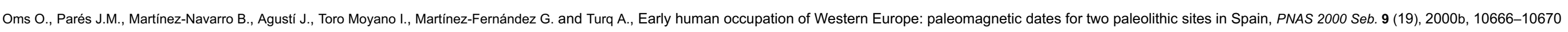
http://doi.org/10.1073/pnas.180319797.

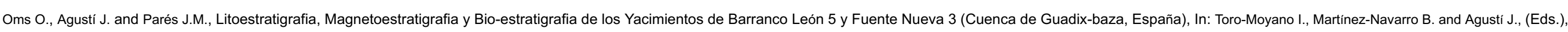
Ocupaciones Humanas en el Pleistoceno inferior y medio de la Cuenca de Guadix-Baza Junta de Andalucía. Consejería de Cultura Monografico, 2010, 107-120.

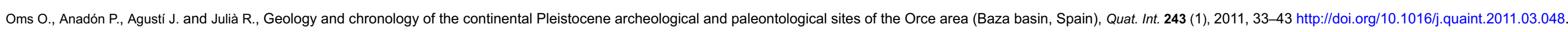

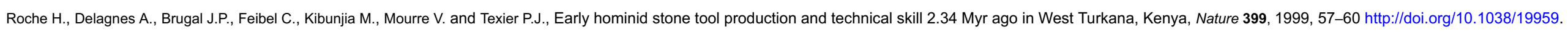

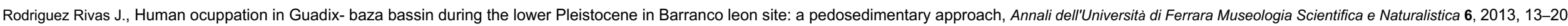
http://doi.org/10.15160/1824-2707/407.

Roebroeks W., From Find Scatters to Early Hominid Behaviour: a Study of Middle Palaeolithic riverside Settlements at Maastricht-belvédère (the Netherlands). Analecta Praehistorica Leidensia vol. 21, 1988, 197 University of Leiden.

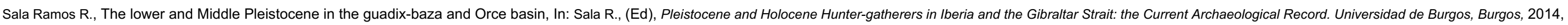
$472-488$.

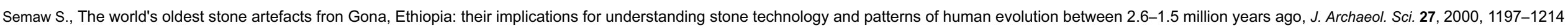
http://doi.org/10.1006/jasc.1999.0592.

Semaw S., Renne P., Harris J.W.K., Feibel C.S., Bernor R.L., Fesseha N. and Mowbray K., 2.5-million-yearold stone tools from Gona, Ethiopia. Nature 385, 1997, 333-336 http://doi.org/10.1038/385333a0.

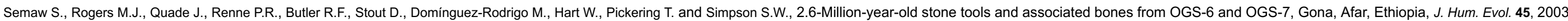
169-177 http://doi.org/10.1016/S0047-2484(03)00093-9.

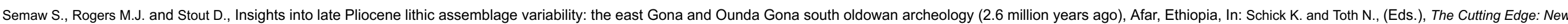
Approaches to the Archaeology of Human Origins, 2009, Stone Age Institute Press, Indiana University; Bloomington, 211-246.

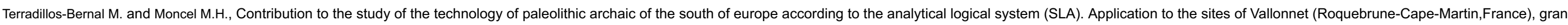
dolina TD6 (burgos, Spain), cà belvedere of monte poggiolo (forli, Italy) and Barranco León and Fuente Nueva 3 (Orce, Spain), Anthropologie 108 (3-4), $2004,307-329$ http://doi.org/10.1016/j.anthro.2004.10.001.

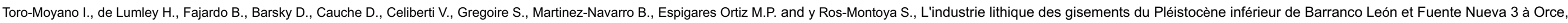
Grenade, Espagne, Anthropologie 113 (1), 2009, 111-124 http://doi.org/10.1016/j.anthro.2009.01.006.

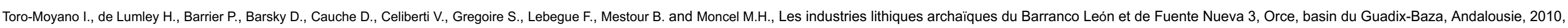
CNRS Editions; Paris.

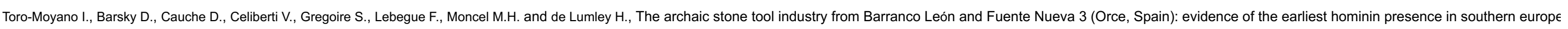
Quat. Int. 243 (1), 2011, 80-91 http://doi.org/10.1016/j.quaint.2010.12.011. 


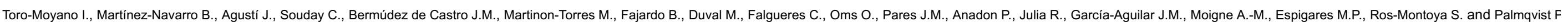
The oldest human fossil in Europe, from Orce (Spain), J. Hum. Evol. 65 (1), 2013, 1-9 http://doi.org/10.1016/j.jhevol.2013.01.012.

Vaquero M., The history of stones: behavioural inferences and temporal resolution of an archaeological assemblage from the Middle Palaeolithic, J. Archaeol. Sci. 35, $2008,3178-3185$.

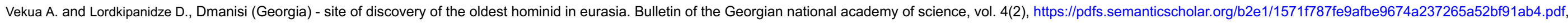
2010, Accessed 20 March 2018.

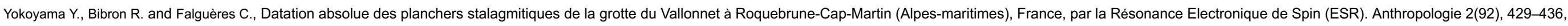
https://halshs.archives-ouvertes.fr/halshs-00406219, 1988, Accessed 20 March 2018.

\section{Appendix A. Supplementary data}

The following are the supplementary data related to this article:

Multimedia Component 1

Supplementary material 2

alt-text: Supplementary material 2

Multimedia Component 2

Supplementary material 1

alt-text: Supplementary material 1

Highlights

- Barranco León is the best European collection of Oldowan percussive tools.

- First detailed study with data of Oldowan active percussive tools from Barranco León.

- Experimental research reveals possible percussive activities of Oldowan hominins.

- Unique methodology provides a template for studying ancient percussive technologies.

- Archeological and experimental data reveals possible Oldowan hominin activity.

\section{Queries and Answers}

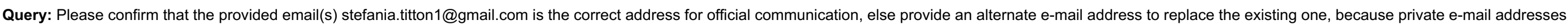
should not be used in articles as the address for communication

Answer: I confirm that the provided email stefania.titton1@gmail.com is correct

Query: Please check the address for the corresponding author that has been added here, and correct if necessary.

Answer: The address for the corresponding author is correct

Query: Please note that 'Fig. 5' was not cited in the text. Please check that the citation(s) suggested by the copyeditor are in the appropriate place, and correct if necessary.

Answer: The citation "Fig. 5" is not in the appropriate place. See "Instruct". I underline the correct position 
Query: Ref(s).Lumley et al. (2005); Linneo, 1753 are cited in the text but not provided in the reference list. Please provide it/them in the reference list or delete these citations from the text.

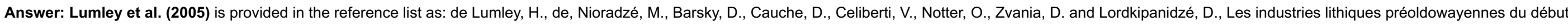
du Pléistocène inférieur du site de Dmanissi en Géorgie. Anthropologie 109(1), 2005,1-182. http://doi.org/10.1016/j.anthro.2005.02.011 For Linneo, 1753 provide the citation. See "instruct"

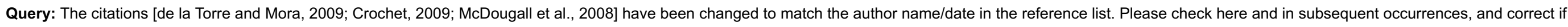
necessary.

Answer: Looks fine

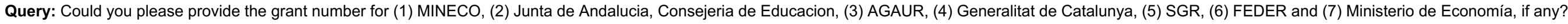
Answer: There is no grant number

Query: Please confirm that given names and surnames have been identified correctly and are presented in the desired order and please carefully verify the spelling of all authors' names.

Answer: Yes

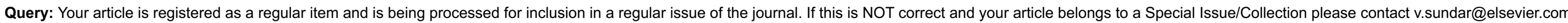
immediately prior to returning your corrections.

Answer: Yes 